
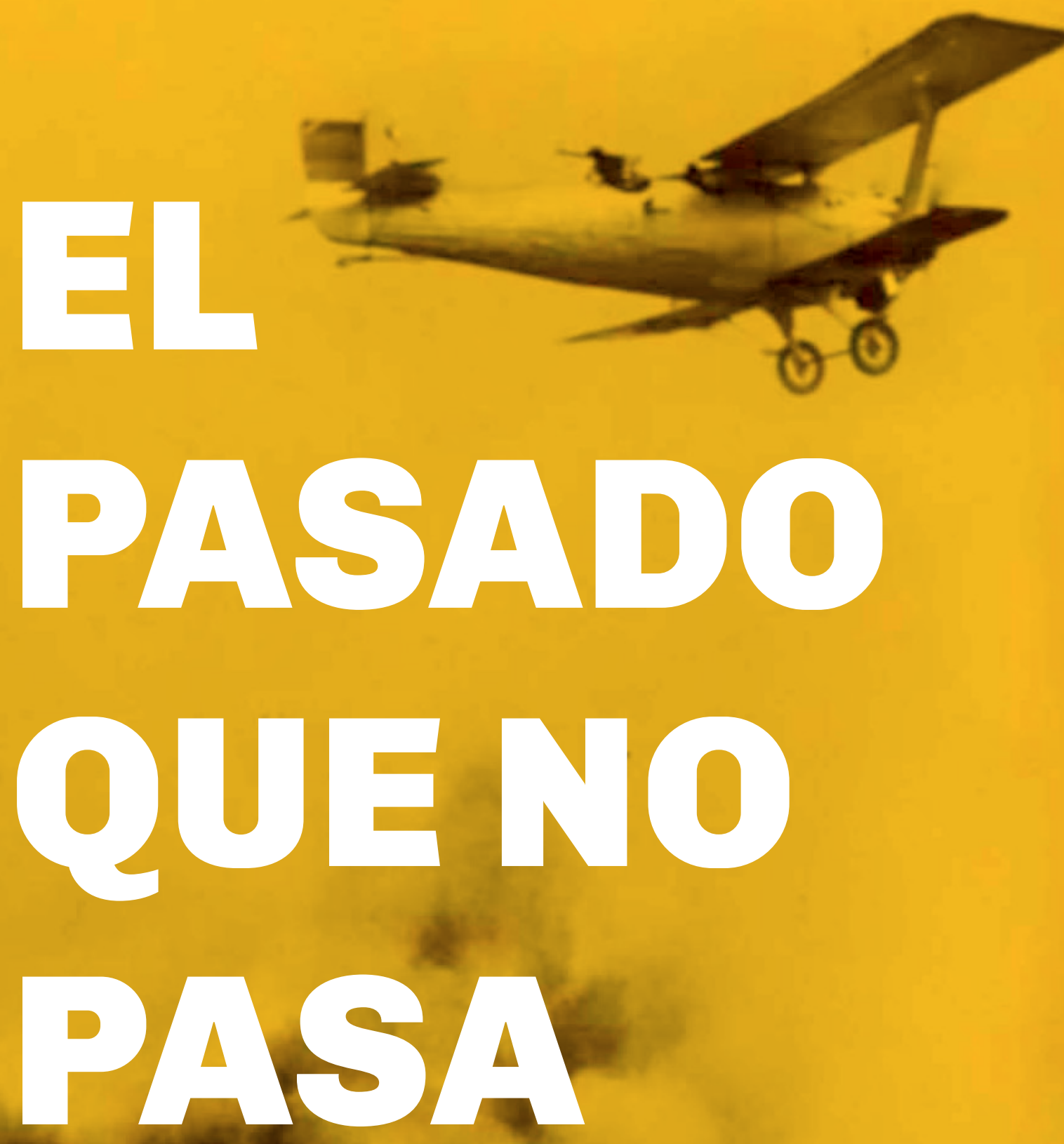

\title{
LA GUERRA CIVIL ESPAÑOLA
} A LOS OCHENTA AÑOS DE SU FINALIZACIÓN

EDUARDO HIGUERAS

ÁNGEL LUIS LÓPEZ VILLAVERDE SERGIO NIEVES CHAVES (COORD.)

(1) $\frac{\text { Ediciones de la Universidad }}{\text { de Castilla-La Mancha }}$ 



\title{
El pasado que no pasa: la Guerra Civil española a los ochenta años de su finalización
}

\author{
Eduardo Higueras Castañeda \\ Ángel Luis López Villaverde \\ Sergio Nieves Chaves \\ (Coordinadores)
}

Ediciones de la Universidad

Cuenca, 2020 


\section{EL PASADO QUE NO PASA: LA GUERRA CIVIL ESPAÑOLA A LOS OCHENTA AÑOS DE}

SU FINALIZACIÓN

La Guerra civil española (1939-1936), 80 años después, Albacete, 29 y 30 de octubre de 2018 / coordinado por, Eduardo Higueras Castañeda, Ángel Luis López Villaverde, Sergio Nieves Chaves.- Cuenca : Ediciones de la Universidad de Castilla-La Mancha, 2020

520 p. ; 29,7 cm.- (Jornadas y Congresos ; 26)

ISBN 978-84-9044-374-3

1. España - Historia 1936-1939 (Guerra civil) I. Higueras Castañeda, Eduardo, coord. II. López Villaverde, Ángel Luis. III. Nieves Chaves, Sergio IV. Universidad de Castilla-La Mancha, ed. V. Título VI. Serie

NHD - 1DS3 - 3JK

(C) de los textos e ilustraciones: sus autores

(C) de la edición: Universidad de Castilla-La Mancha

Edita: Ediciones de la Universidad de Castilla-La Mancha, CEDOBI, Seminario Permanentes de Estudios Contemporáneos.

Colección JORNADAS Y CONGRESOS n. ${ }^{\circ} 26$

Revisores: Alba Nueda Lozano y Sergio Nieves Chaves.

Imagen de cubierta: Aviones nacionales derribados por los republicanos. Biblioteca Digital Hispánica. CC BYNC-SA 4.0. Recuperado de http://shorturl.at/lrvAT

El procedimiento de selección de originales se ajusta a los criterios específicos del campo 10 de la CNEAI para los sexenios de investigación, en el que se indica que la admisión de los trabajos publicados en las actas de congresos deben responder a criterios de calidad equiparables a los exigidos para las revistas científicas y capítulos de libros.

E1 Seminario Permanente de Estudios Contemporáneos (SPEC) es un grupo de investigación emergente de la Universidad de Castilla-La Mancha. Esta edición ha contado con financiación de la UCLM a través de fondos FEDER de la Unión Europea.

E1 Centro de Estudios y Documentación de las Brigadas Internacionales (CEDOBI) es un centro mixto de investigación del Instituto de Estudios Albacetenses "Don Juan Manuel” (IEA) y de la Universidad de CastillaLa Mancha.

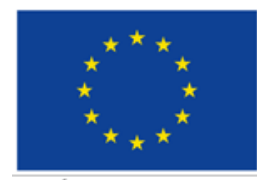

UNIÓN EUROPEA

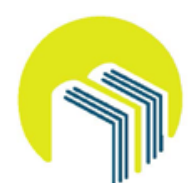

Seminario Permanente Estudios Contemporáneos

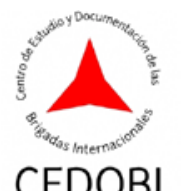

CEDOBI

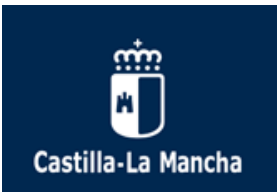

11 Esta editorial es miembro de la UNE, lo que garantiza la difusión y comercialización de sus publiUNín De ED TORRL.Rs caciones a nivel nacional e internacional

I.S.B.N.: 978-84-9044-374-3 (Edición impresa)

D.O.I.: http://doi.org/10.18239/jornadas_2020.26.00

Composición: Compobell

Hecho en España (U.E.) - Made in Spain (U.E.)

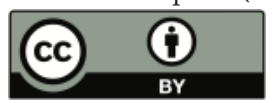

Esta obra se encuentra bajo una licencia internacional Creative Commons CC BY 4.0.

Cualquier forma de reproducción, distribución, comunicación pública o transformación de esta obra no incluida en la licencia Cretative Commons CC BY 4.0 solo puede ser realizada con la autorización expresa de los titulares, salvo excepción prevista por la ley. Puede Vd. acceder al texto completo de la licencia en este enlace: https:// creativecommons.org/licenses/by/4.0/deed.es

Impreso en España (U.E.) - Printed in Spain (E.U.) 


\section{ÍNDICE}

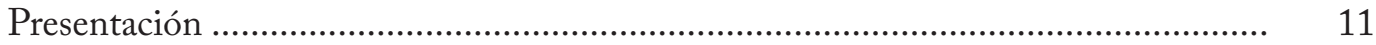

Ángel Luis López Villaverde, Eduardo Higueras Castañeda y Sergio Nieves Chaves

El frente de Granada: vida cotidiana y bombardeos aéreos y marítimos ................... Francisco Jesús Martín Milán

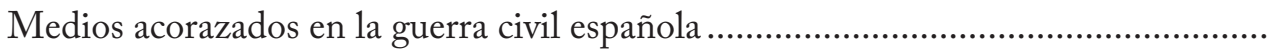
Juan Pastrana Piñero

Bombas que nunca mataron: el sabotaje pacífico durante la guerra civil española .... Alfonso López García

Propaganda, música y sabotaje en la guerra civil española: canciones patrióticas

premiadas por la Junta Recaudatoria Civil de Zaragoza ........................................... Marco Antonio de la Ossa Martínez

La lucha en la retaguardia. La Brigada Terry, Madrid 1936.

Robert Duró Fort

Burgos bajo sospecha: la investigación de los servicios secretos para desarticular un posible complot contra Franco durante la guerra civil

Clara Sanz Hernando, Miguel A. Moreno Gallo y José Maria Chomón Serna

Una lenta e intensa agonía: el desgaste de la retaguardia republicana por el hambre a través del abastecimiento de Madrid en el último año de la guerra (1938-1939)... Ainhoa Campos Posada

La quinta columna en la retaguardia republicana de Cataluña

Javier Rodríguez Abengózar

La CNT y la Comarcal de Quintanar de la Orden, ¿Anarquistas o fascistas?

Vicente Torres Encinas

Octubre de 1934 en la represión de guerra y postguerra en Ciudad Real

Juan Carlos Buitrago Oliver

Revolución, violencia, contrarrevolución: Almagro, 1936-1939*

Ángel Luis López Villaverde

La justicia republicana durante la guerra civil: los tribunales Especial Popular y

Especial de Guardia de Cuenca

Sergio Nieves Chaves

La represión en grupo como búsqueda de la "ejemplaridad" y la coacción por la justicia del miedo 
Cárceles españolas durante la guerra civil: la verdad intramuros

María José Palazón Pagán

Nuestra Lucha (1936)

Joaquin Navarro Caravaca

La contribución de las salmantinas a la financiación de la guerra civil: una nueva modalidad de participación femenina

M. ${ }^{a}$ Luz de Prado Herrera

Milicianas, guerrilleras y mujeres de rojo: tres modalidades de lucha y resistencia frente a los sublevados. El ejemplo de León

Beatriz García Prieto

Mujeres combatientes en el ejército popular de la República (1936-1939).

Sara Hernández Martín y Luis A. Ruiz Casero

De la documentación a la presentación del patrimonio de la guerra civil española: el caso del nido de ametralladoras de Alhama de Murcia (Murcia, España)

Victor Manuel López-Menchero Bendicho, Herbert D. G. Maschner, Francisco José Fernández Guirao, Jeffrey DuVernay, Miguel Ángel Hervás Herrera, James Bart McLeod, Aurelia Lureau y José Baños Serrano

Los fortines de los rojos. Búnkeres de la costa catalana: patrimonio inmueble de la guerra civil en riesgo

Anna Soret Miravet

¡Sabotaje! Arquitectura militar y defensa de costas entre Murcia y Almería durante la guerra civil española

Francisco José Fernández Guirao

"Vivir y morir en la trinchera". Patrimonio, memoria y didáctica del frente de San Isidro (Puebla de Lillo, León).

Victor Bejega García, Irene García Lino y Eduardo González Gómez de Agüero

Aprender investigando: la imagen de las mujeres republicanas en la prensa gráfica durante la guerra civil española

(1936-1939)

Félix González Chicote

Enterrar a los muertos. Explicar las fosas comunes de la guerra civil a través de los clásicos de la literatura

Alejandro Lillo

Reescribiendo Guadalajara. El tratamiento iconográfico de la guerra civil española en los primeros números de El Legionario

Daniela Aronica

Il tesoro degli anarchici. El exilio italiano en España y la compra de armas para la

República: algunos pícaros y un ministro, 1936-1937.

Antonio Calzado Aldaria y Bernat Martí i Pellicer

La sección francesa del Comité Mundial de Mujeres contra la Guerra y el Fascismo y la guerra civil española (1936-1939).

Rocio Negrete Peña

Brigadistas sanitarios en la guerra de España. De la solidaridad internacional a los campos nazis... 
La dimensión internacional de la salida del Consejo Nacional de Defensa, marzo de 1939

\section{Eladi Mainar Cabanes, Robert Llopis i Sendra}

La evolución ideológica de los militares: al golpismo o la defensa de la II República. Los ejemplos del general Fanjul y el teniente coronel Fernández Navarro Herminio Lebrero Izquierdo

Poder y resistencia después de la guerra civil española: el caso de Teresa/Florencio Pla Messeger .....

Lissette Rolón Collazo

Aproximación al estudio de la represión política de posguerra, a través del fondo de la cárcel provincial de Cuenca (1939-1945).... 



\title{
Aprender investigando: la imagen de las mujeres republicanas en la prensa gráfica durante la guerra civil española (1936-1939)
}

\author{
Félix González Chicote* \\ IES Margarita Salas (Seseña, Toledo) \\ http://doi.org/ıo.I8239/jornadas_2020.26.23
}

\section{LA HISTORIA ESCOLAR, APOCALIIPTICOS E INTEGRADOS}

El 5 de enero de 2017 el programa Ahora Caigo de Antena 3 fue testigo del duelo televisivo entre dos jóvenes concursantes, Alex y Nacho. Ambos debían adivinar un tema a medida que el presentador iba dando pistas. El tema era la Guerra Civil Española y ambos necesitaron ro pistas para llegar a la respuesta adecuada. El vídeo se convirtió en viral en las redes sociales, se debatió el asunto en diversas emisoras de radio y la prensa escrita se hizo eco del asunto. Las afirmaciones, en líneas generales, oscilaron entre "la escasa cultura sobre la Guerra Civil de los jóvenes españoles" y "la generación más preparada de la historia dando muestras de su sabiduría”.

Sin embargo, menos repercusión tuvo la reacción de unos alumnos de Bachillerato del Instituto Brugers de Gavà (Barcelona) que en 2016 iniciaron la campaña "Retirada: Lo que escondian sus ojos" en la plataforma Change.org logrando recoger más de cuarenta mil firmas. La miniserie, protagonizada por la actriz Blanca Suárez trataba sobre la relación amorosa entre el ministro de Asuntos Exteriores hasta 1942, Ramón Serrano Suñer, y la marquesa de Llanzol. La actriz, cuestionada en algunas redes sociales reaccionó afirmando: "no hagáis populismo, que sois muy jóvenes para empezar ya así. Un besito fuerte". Para los impulsores de la campaña, sin embargo, la serie era una "banalización de uno de los períodos más oscuros y crueles de la historia de España”. El argumento de los promotores, influido por las ideas de Hannah Arendt, puede interpretarse como una señal del compromiso con la memoria democrática de las nuevas generaciones de estudiantes.

Ambos ejemplos demuestran que no resulta tan sencillo levantar acta del nivel de conocimiento y conciencia histórica de nuestros jóvenes. Sin embargo, algunos análisis académicos recientes como los realizados por el grupo DICSO de la Universidad de Murcia se inclinan por un medido pesimismo afirmando que, desde un punto de vista global, tenemos un modelo de educación histórica con problemas. La descripción de los problemas siempre nos remite

* Nota aclaratoria: Se hace constar que el uso de fotografías en este trabajo persigue una finalidad exclusivamente académica, sin otra pretensión o finalidad y se reivindica la pertinencia de reconocer las imágenes del pasado y su contribución al relato histórico. 
a la enseñanza memorialista y a los achaques de un modelo curricular donde los contenidos conceptuales han ido ganando peso desde 1990 (GÓMEZ y MIRALLES, 2017: 219).

Al mismo tiempo que se diagnostican los problemas, se suele adoptar un enfoque que podríamos definir como regeneracionista, que apuesta casi todo a las nuevas estrategias metodológicas (Visual Thinking, Flipped Classroom, "gamificación”, etc.) y que olvida que, más allá del tópico del profesor guardián de la tradición y esclavo de la rutina (profesor monologuista), existe una dimensión crítica esencial en su quehacer diario de transmisión de esa parcela cultural que llamamos currículum escolar.

Los contenidos escolares, al margen de una mejor o peor metodología utilizada en clase, no son materia prima, son productos elaborados resultado de un proceso donde no podemos perder de vista el papel de unos agentes recontextualizadores como el Estado, encargado de la gestión de la memoria colectiva (PÉREZ GARZÓN, 2000: 25) y el mercado de libros de texto. El resultado es un crecimiento, homogeneización, estandarización y control de la vida en las aulas que convive paradójicamente con las retóricas de la innovación educativa que suelen orillar la dimensión crítica y la relevancia de la dimensión de identidad y compromiso para la significación del conocimiento histórico (MARTÍNEZ VALCÁRCEL, 20I4: 258).

En este sentido, creemos conveniente recuperar la propuesta para una didáctica crítica de la historia planteada hace unos años por Raimundo Cuesta. Para el autor y los miembros del colectivo FEDICARIA el conocimiento histórico debe ayudar a pensar históricamente en sintonía con el clásico consejo de Pierre Vilar, "la historia debe enseñarnos, en primer lugar, a leer un periódico". De igual modo, debe tener como ejes la problematización genealógica del presente, el replanteamiento de la producción y uso de materiales didácticos, el cuestionamiento de las narrativas identitarias y el rescate de nuevos agentes históricos (CUESTA, 2007: 62).

El profesor de historia debe considerar el pasado como una realidad plástica, un libro abierto en permanente construcción desde diferentes miradas y experiencias sociales. El pasado está siempre por descubrir y esa dimensión fluyente del pasado y su recuerdo representan una parte muy sustancial del valor educativo de la historia como cruce de memorias y contramemorias (CUESTA, 2007: 55).

En sintonía con lo anterior, la propuesta didáctica que hemos desarrollado con nuestros alumnos pretende rescatar el papel activo de la mujer en la zona republicana durante la guerra civil a través de lo que María Olivera Zaldua ha llamado la "mirada roja", es decir, la profusión de imágenes fotográficas aparecidas durante el conflicto en la prensa y el papel del reporterismo gráfico en la zona republicana (DE LAS HERAS, 20I7: IO3). El planteamiento permite ir más allá del currículum de Historia de España para $2^{\circ}$ de Bachillerato convirtiendo la visibilidad de la mujer durante la guerra civil en el tema principal y dejando en manos del alumnado la construcción del propio contenido de aprendizaje a través de una metodología basada en la elaboración de pequeñas investigaciones colaborativas que dan sentido al proyecto común.

El uso de prensa digitalizada ha permitido el contacto directo con las fuentes y afrontar uno de los principios básicos que establece el currículo de la materia: "nuestros alumnos deben percibir claramente que la Historia es una ciencia y que el historiador sigue un método científico, propio de las ciencias sociales, a la hora de sumergirse en el estudio del pasado". Todo ello ha incitado que los alumnos descubran que el relato histórico materializado en sus apuntes de clase constituye una síntesis interpretativa que difícilmente puede abordar la multiplicidad de experiencias humanas con las que han tenido contacto en su investigación. El tópico de los tediosos y extensos apuntes de historia cuya memorización no encontraba cauce y sentido se ha convertido en la toma de conciencia de la geología más compleja que esconde esa superficial capa histórica que abordamos durante tres horas a la semana. Por otro lado, ha resultado un 
descubrimiento para los alumnos la posibilidad de viajar al pasado a golpe de clic desde la silla de casa a través de la hemeroteca digital de la Biblioteca Nacional.

\section{OBJETIVOS DEL PROYECTO}

Un somero análisis del currículo de la materia de Historia de España del $2^{\circ}$ curso de Bachillerato en Castilla-La Mancha evidencia rápidamente, a nuestro juicio, tres problemáticas: el desbordante desequilibrio entre el marco cronológico a desarrollar (de la Prehistoria al problema catalán) y las sesiones anuales para desarrollarlo, la secuenciación por reinados de los contenidos, privilegiando el enfoque político y convirtiendo a la monarquía en el principal agente de la historia y, en último lugar, pero no menos importante, el silencio sobre el papel de las mujeres, síntoma de la desconexión entre las temáticas desarrolladas por las nuevas tendencias historiográficas y su transposición didáctica en las aulas. Así, dentro del canon de textos históricos que muestran la lenta conquista del sufragio en España nunca aparece el poema titulado "Libertad" que escribiera Carolina Coronado en I846 con los significativos versos "Pero, os digo, compañeras, / que la ley es sola de ellos, / que las hembras no se cuentan / ni hay Nación para este sexo”. Ni los textos periodísticos de publicaciones de carácter republicano como La Igualdad que en I871 abordaban los derechos políticos de la mujer — “¿Por qué no ha de disfrutar los mismos derechos civiles que los hombres? ¿Por qué no ha de gozar de libertad?"-, desde un conocimiento de los avances en otros países: "en Wyoming, en los Estados-Unidos, tienen ya el derecho de votar; por eso forman parte del jurado, y por eso, en fin, hemos de verlas algún día ir a depositar con sus delicadas manos en las urnas de los sufragios el voto de su conciencia...”.

Para abordar la tercera problemática a lo largo del pasado curso escolar 20I7-20I8 los alumnos del segundo curso de todas las modalidades de Bachillerato del IES Margarita Salas recopilaron testimonios visuales de la movilización femenina en la historia contemporánea española con la intención de crear un catálogo de materiales que sirvieran de ejercicios prácticos a futuros estudiantes. Desde los grabados de Goya hasta las más de rooo imágenes de mujeres recopiladas de la prensa republicana durante la Guerra Civil. Algunos ejemplos:

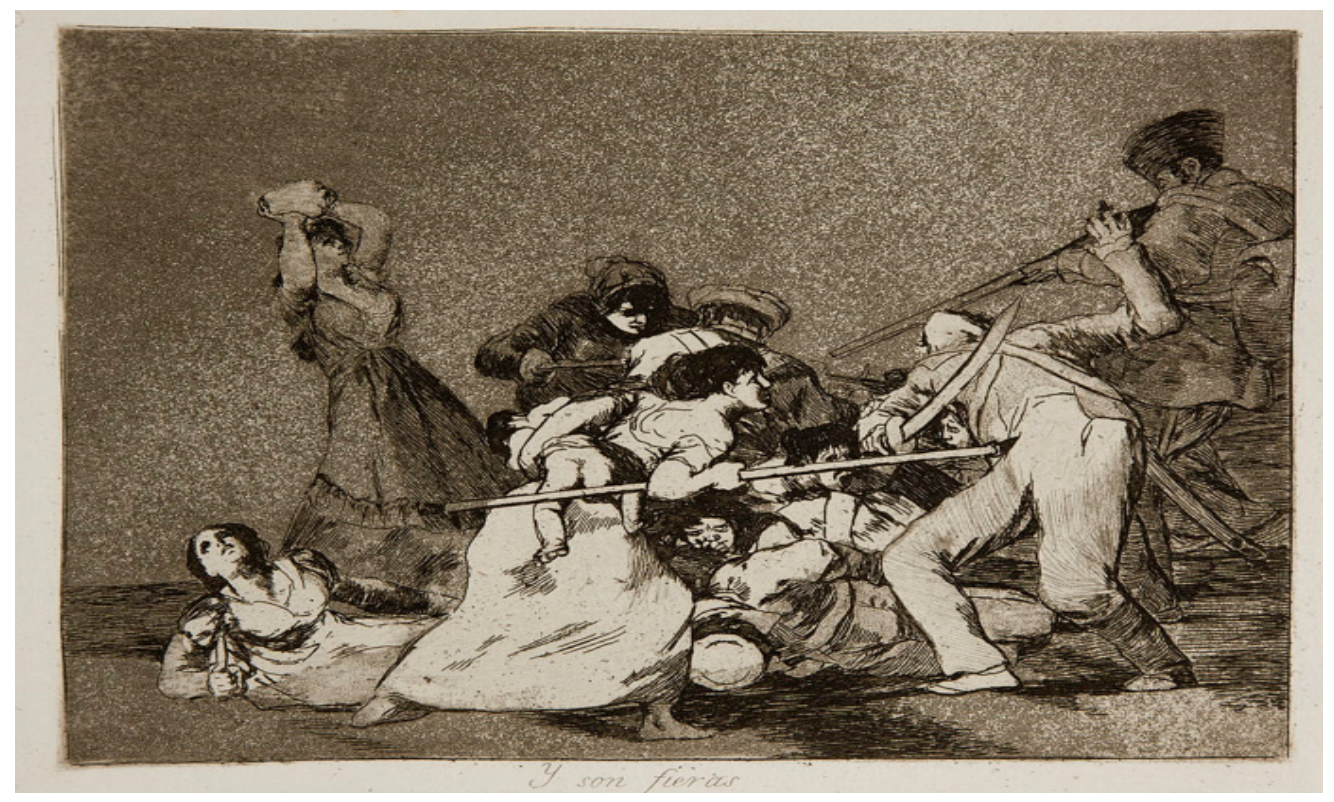

Imagen r. Francisco de Goya, Los desastres de la guerra, núm. 5: "Y son fieras" 


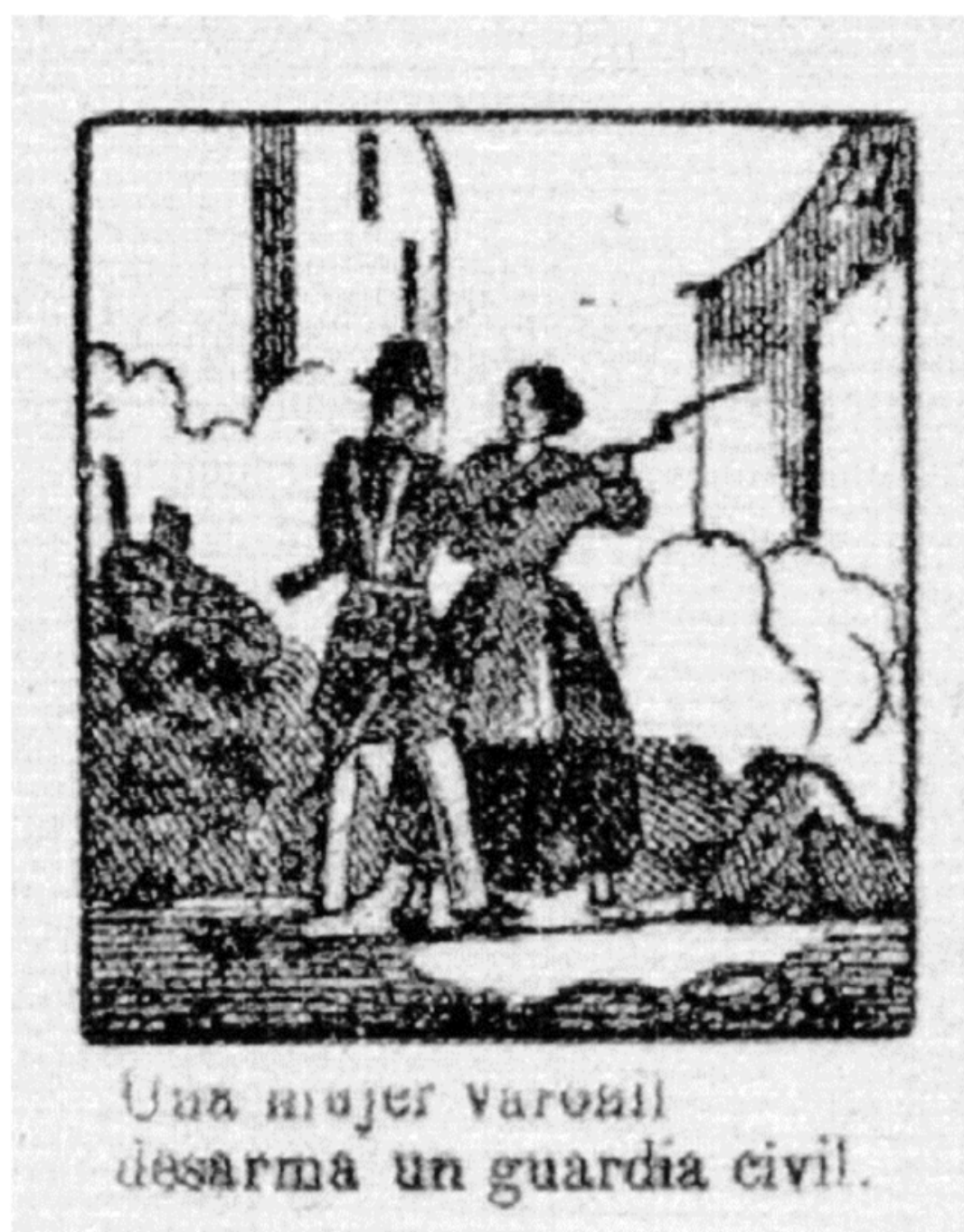

Imagen 2. Viñeta de un Aleluya sobre la revolución de Madrid en julio de I854

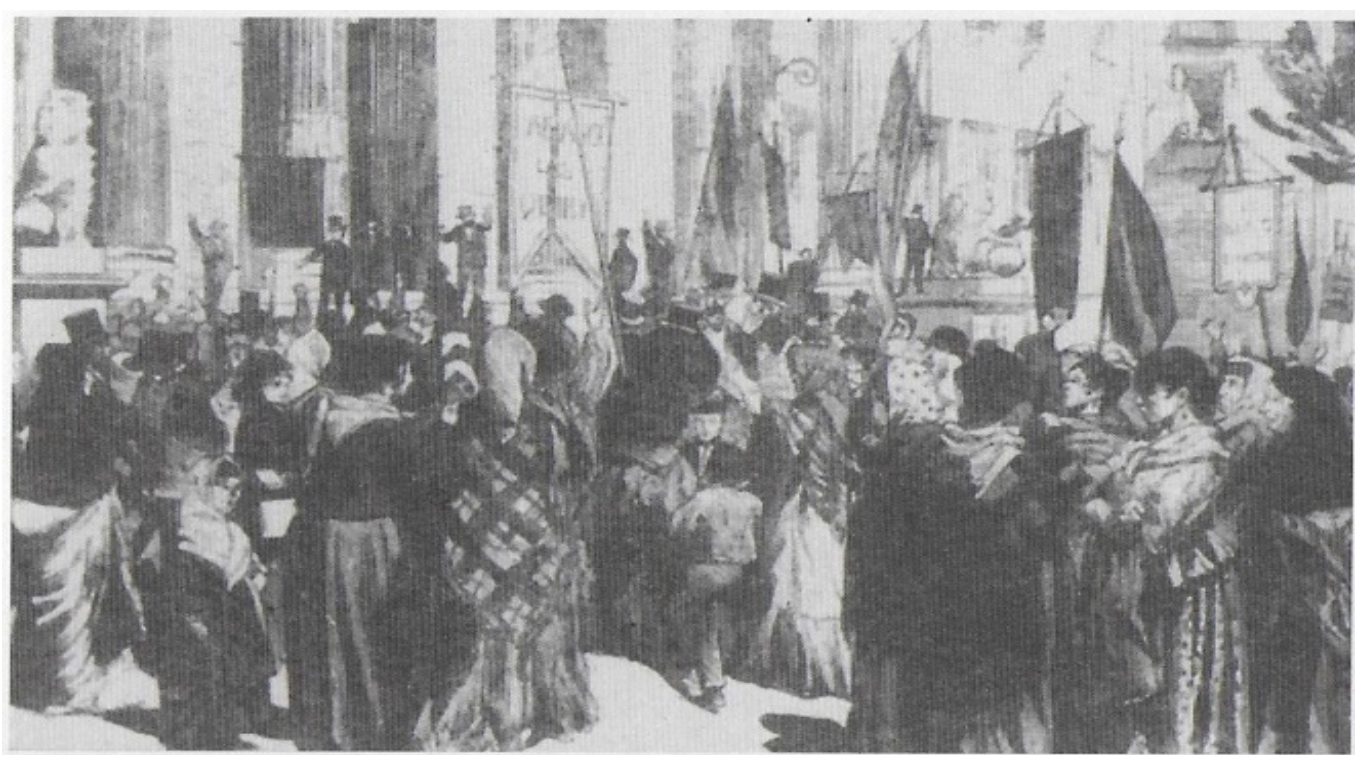

Imagen 3. Manifestación de mujeres madrileñas contra la guerra y las quintas 


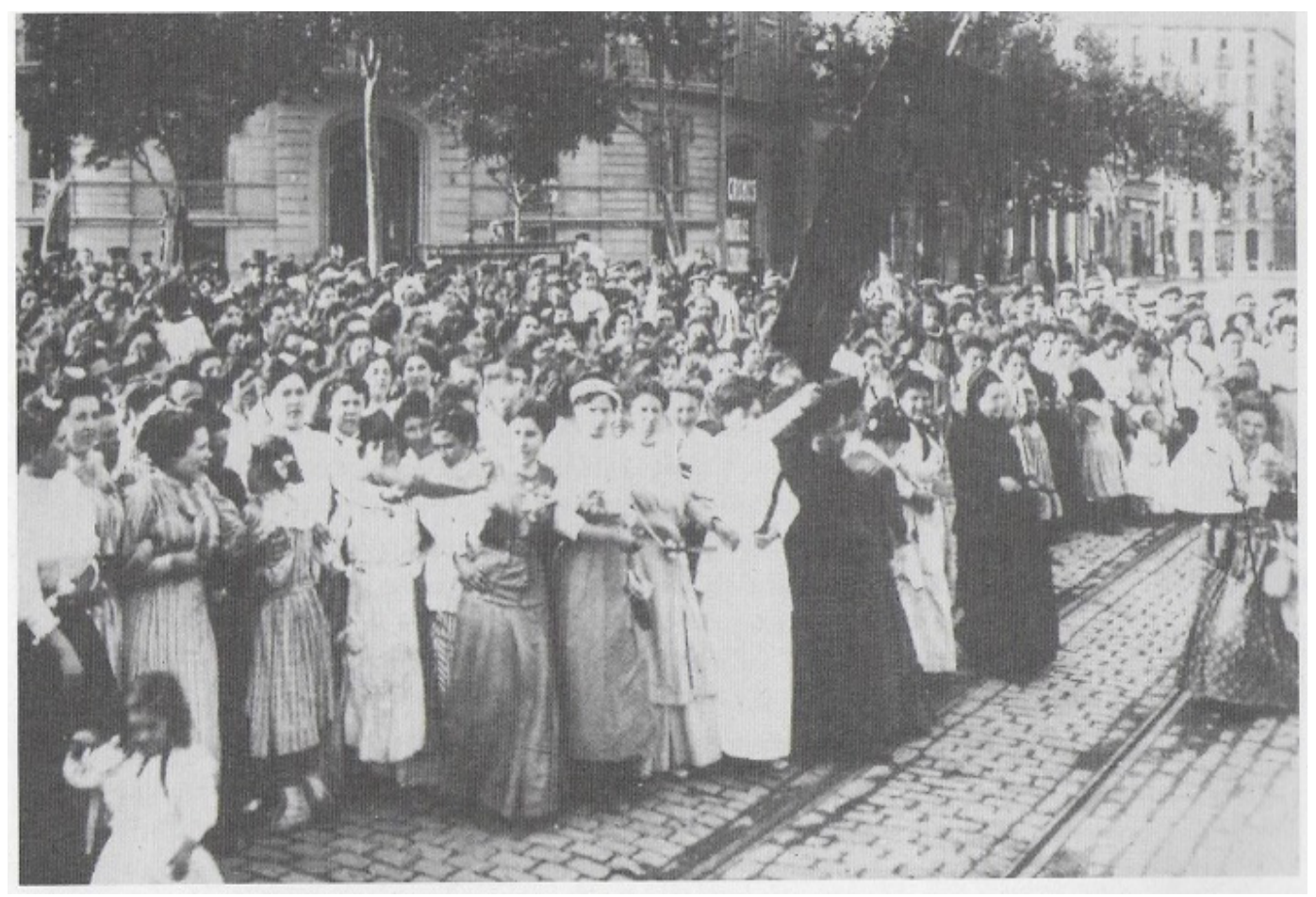

Imagen 4. Manifestación de mujeres contra las guerras, I896
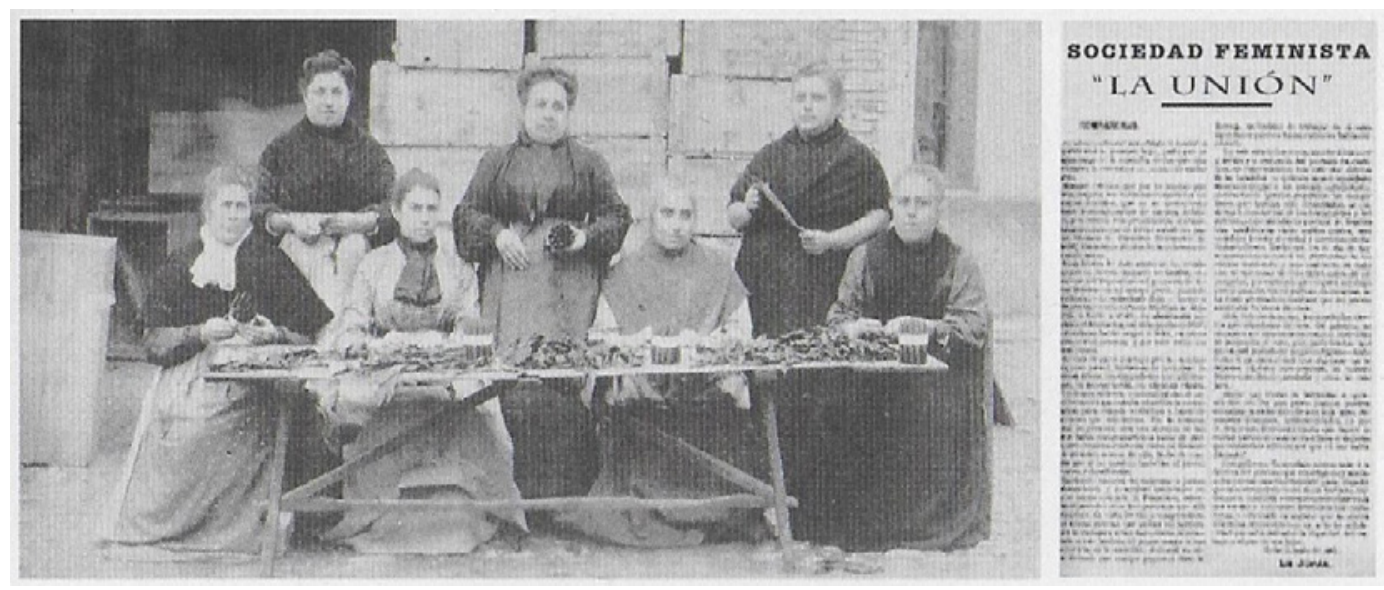

Imagen 5. Organizadoras de La Feminista y panfleto de la Sociedad Feminista la Unión de resistencia y socorros mutuos de Elche

Sin embargo, el momento histórico que con mayor dedicación se ha estudiado ha sido la Guerra Civil Española (1936-1939). La guerra supuso un parteaguas para la condición femenina en España (MARTÍNEZ RUS, 20I8: 35). La democracia republicana había posibilitado derechos y libertades para las mujeres y la guerra aceleró su presencia política y social mediante su participación en los frentes, calles, fábricas, hospitales, mítines o en los cargos públicos.

La selección de la documentación se ha orientado a subrayar la cuestión de la conquista del espacio público y la visibilidad del papel de la mujer durante el conflicto. El paradigma e icono de dicha conquista lo simbolizó en el imaginario colectivo la figura de la miliciana, ejemplo de mujer emancipada, libre e independiente que proliferó en la prensa gráfica hasta la reestructuración y militarización de las milicias de voluntarios con la creación del Ejército 
Popular Regular de la República en octubre de 1936. Desde entonces se generalizó la consigna "el hombre al frente y la mujer a la retaguardia". Así, tras esta breve etapa de esplendor de las mujeres combatientes (de julio a diciembre de 1936) caracterizada por la proliferación de fotografías y portadas dedicadas a las milicianas se examina la significación del papel de la mujer en la retaguardia, convertida en auténtica heroína stajanovista y su regreso al papel de madre y esposa, una vuelta a la iconografía tradicional femenina que vinculaba la maternidad como exponente esencial de la subjetividad femenina, evocando no solo valor y coraje sino también sacrificio (NASH, 2006: 100). El modelo de Dolores Ibárruri Pasionaria, como imagen de la madre combativa sustituyó rápidamente la imagen más rupturista de la miliciana.

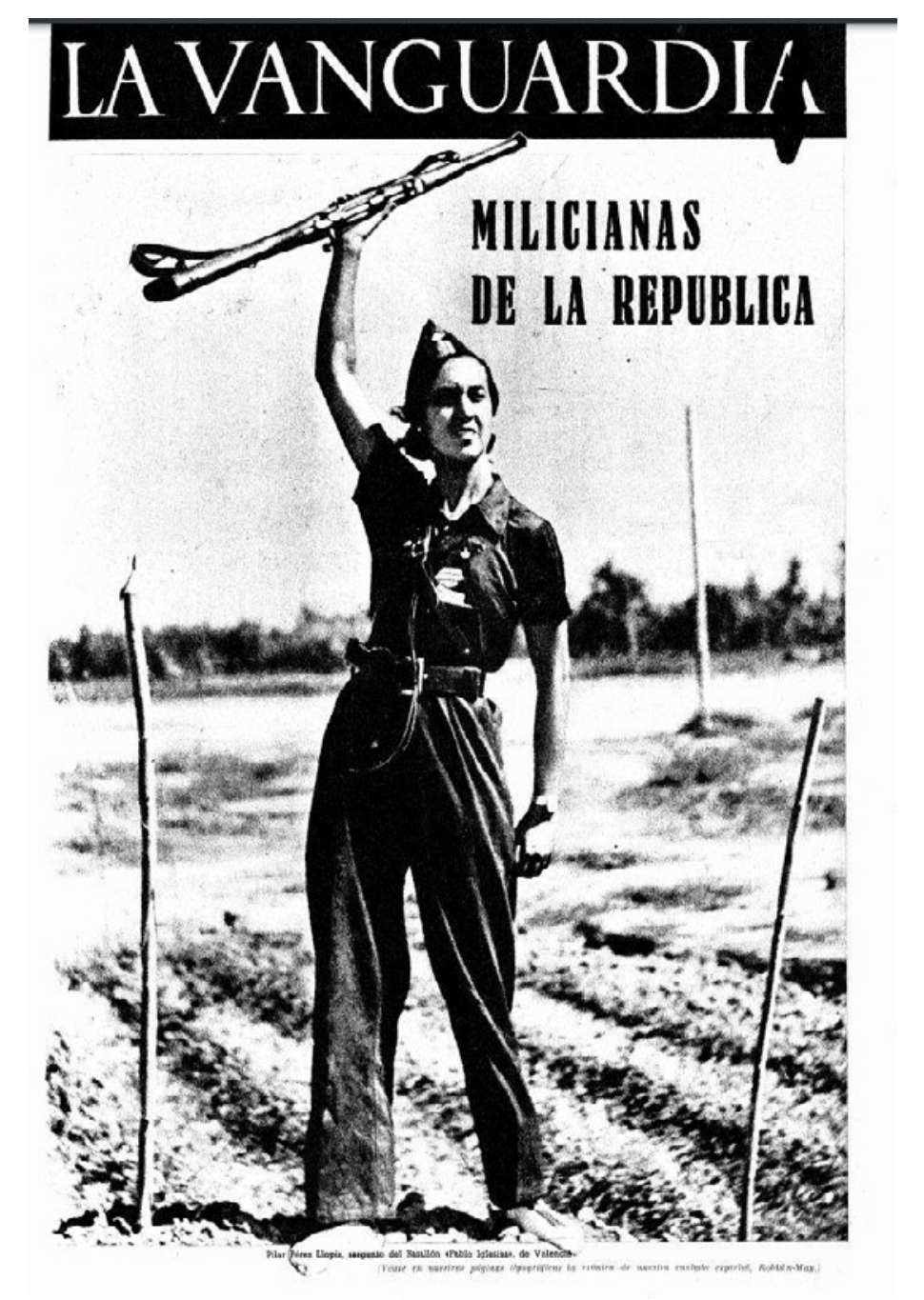

Imagen 6. La Vanguardia, 20 de septiembre de 1936. Portada del suplemento 


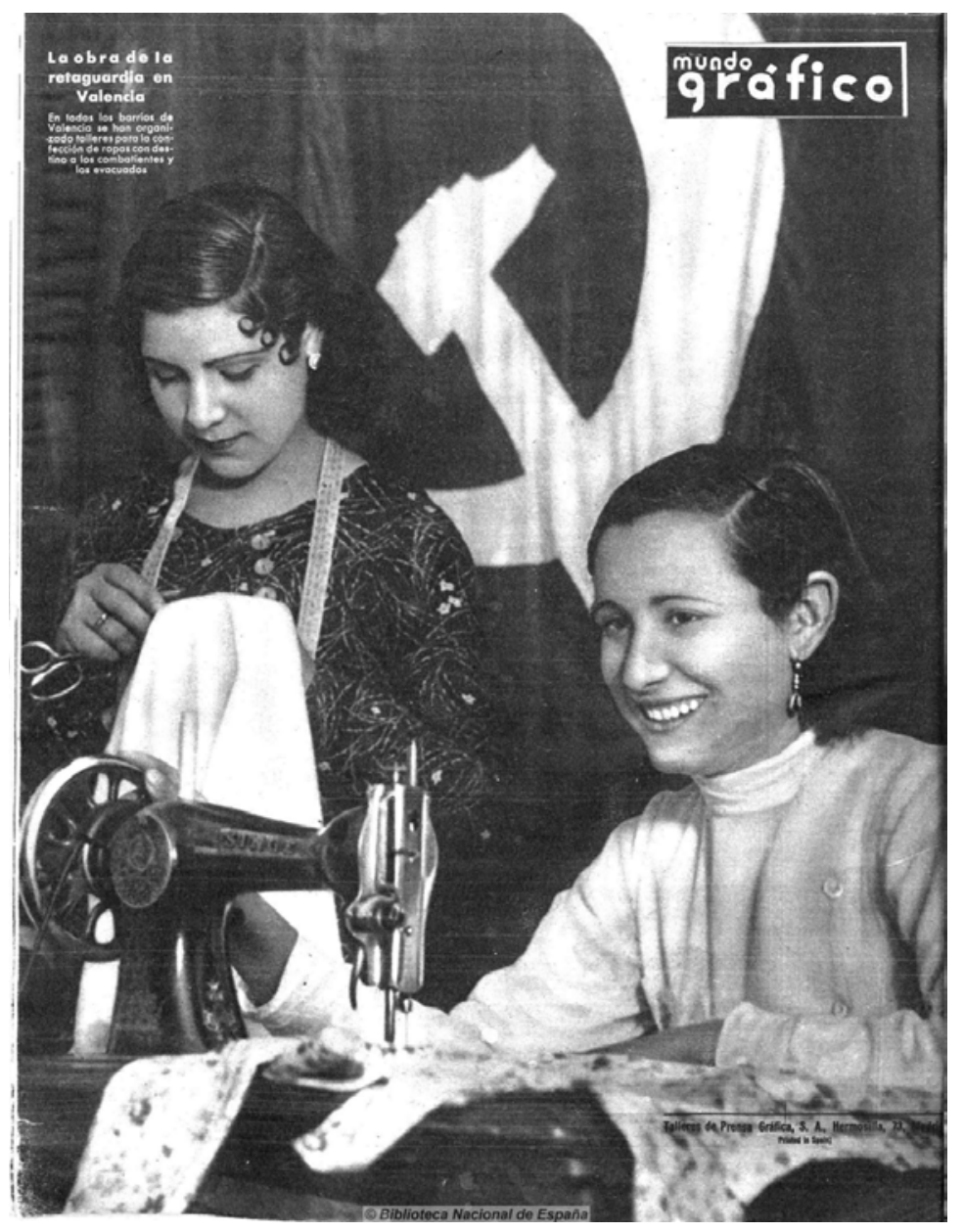

Imagen 7. Portada del Mundo Gráfico del I7 de marzo de 1937

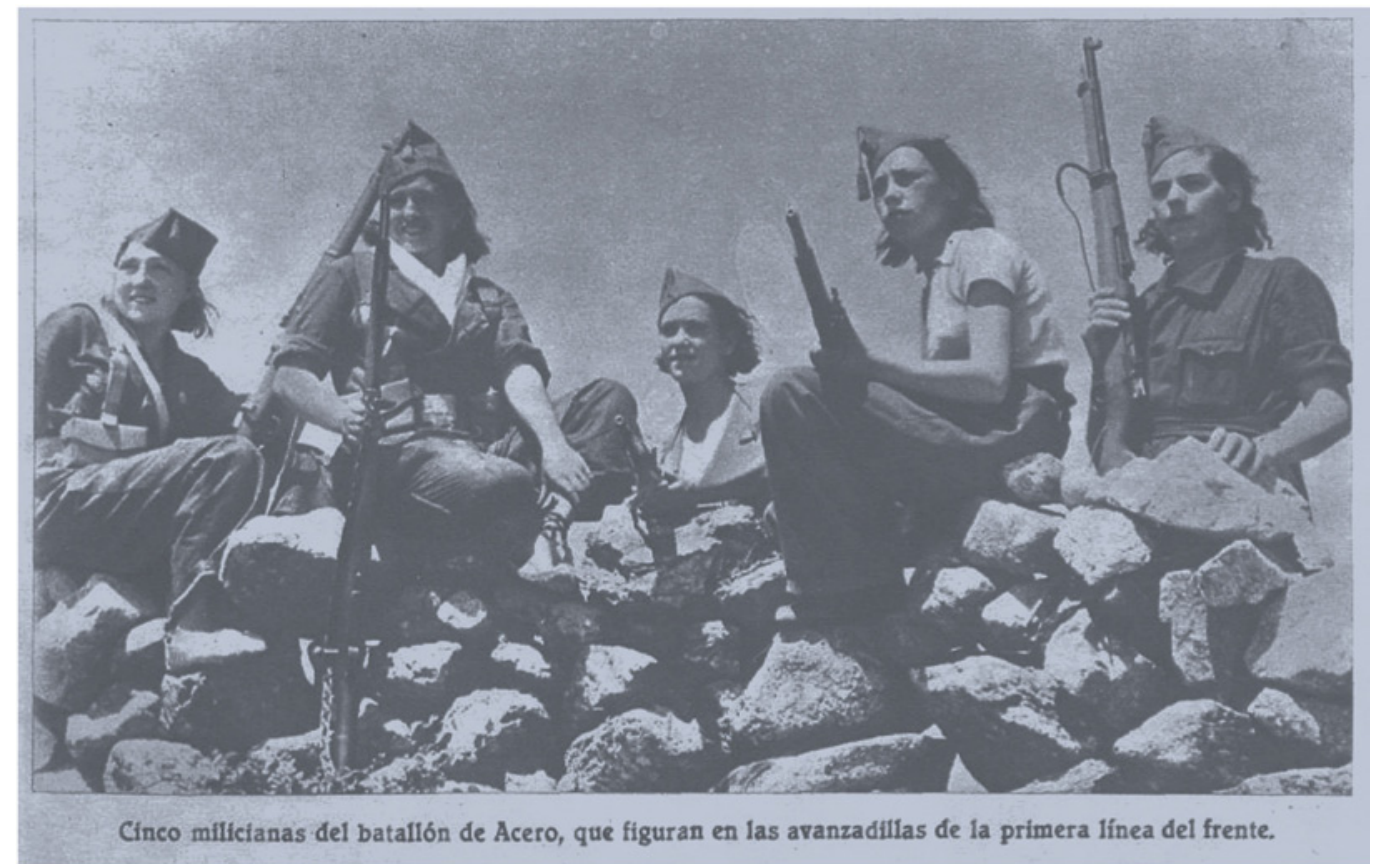

Imagen 8. Crónica, I6 de agosto de 1936, p. 5 


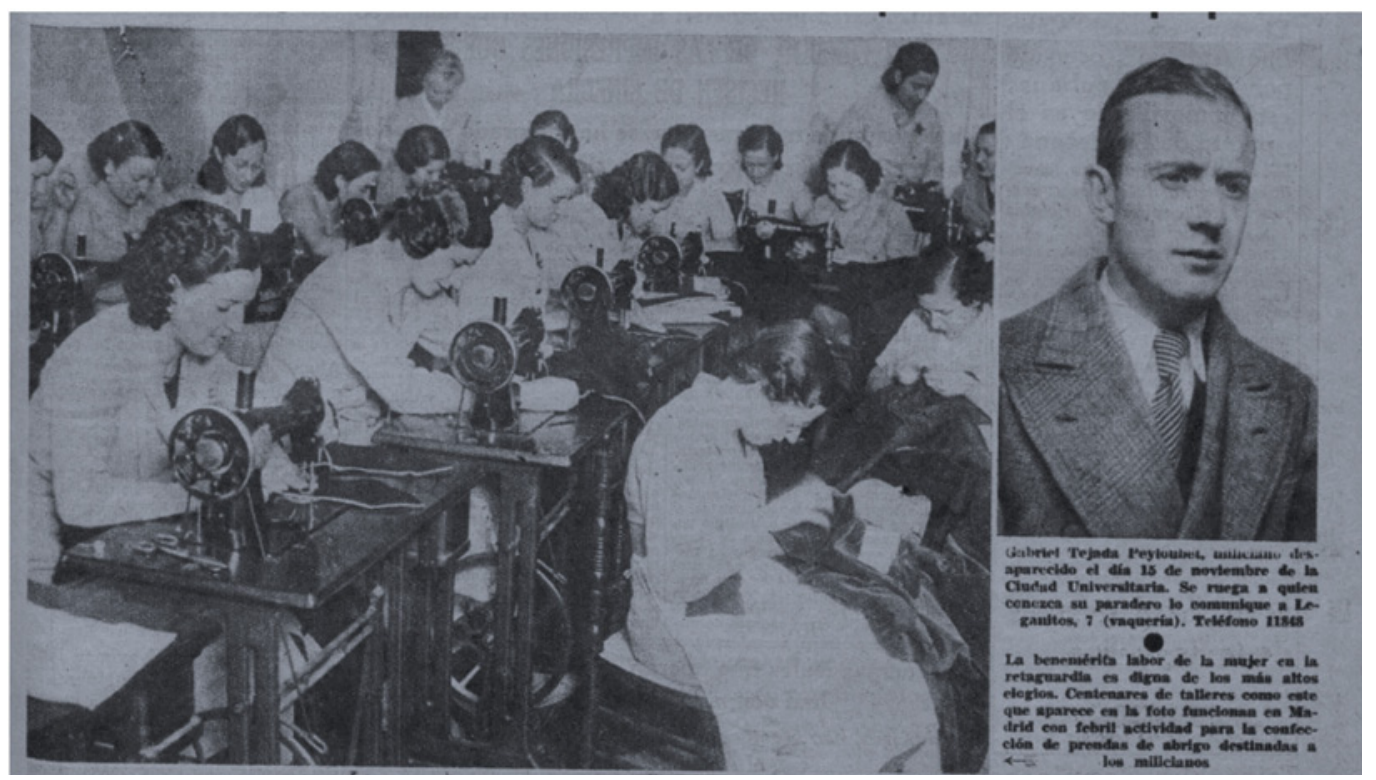

Imagen 9. Ahora, I3 de diciembre de I936, p. 5

La implicación política de las mujeres también se materializó en el acceso a cargos políticos de relevancia. Destaca el nombramiento de Federica Montseny, la primera mujer ministro en España y en Europa occidental. Su incorporación al gobierno de Largo Caballero fue todo un símbolo feminista (MARTÍNEZ RUS, 2018: 45). Por su parte, las mujeres crearon sus propias organizaciones políticas desde diferentes enfoques ideológicos. Cabe, en este sentido, subrayar el ejemplo de la Agrupación de Mujeres Antifascistas, donde primaron las socialistas y, sobre todo las comunistas (MARTÍNEZ RUS, 2018: 47) llegando a estar constituida por más de 255 agrupaciones locales (NASH, 2006: In2). Por su parte, desde el movimiento libertario destacó Mujeres Libres con un número de militantes que oscilaba entre 20.000 y 60.000 según fuentes oficiales (NASH, 2006: г28).

Ambas organizaciones no siempre consideraron la perspectiva de género como primordial, entrando en el dilema programático de priorizar la guerra a la revolución y viceversa y asumiendo las directrices de sus organizaciones políticas matrices: PCE y CNT. Con todo, el anarquismo demostró una mayor sensibilidad ante los temas de género reconociendo la especificidad de la opresión femenina y la necesidad de una lucha autónoma para superarla, por ello, Mujeres Libres desarrolló la estrategia de la "doble lucha" o "doble militancia": una, revolucionaria, basada en la eliminación de la explotación socioeconómica y la desaparición del Estado, y otra, feminista, que cuestionaba la supremacía masculina y las estructuras patriarcales (NASH, 2006: 135). 


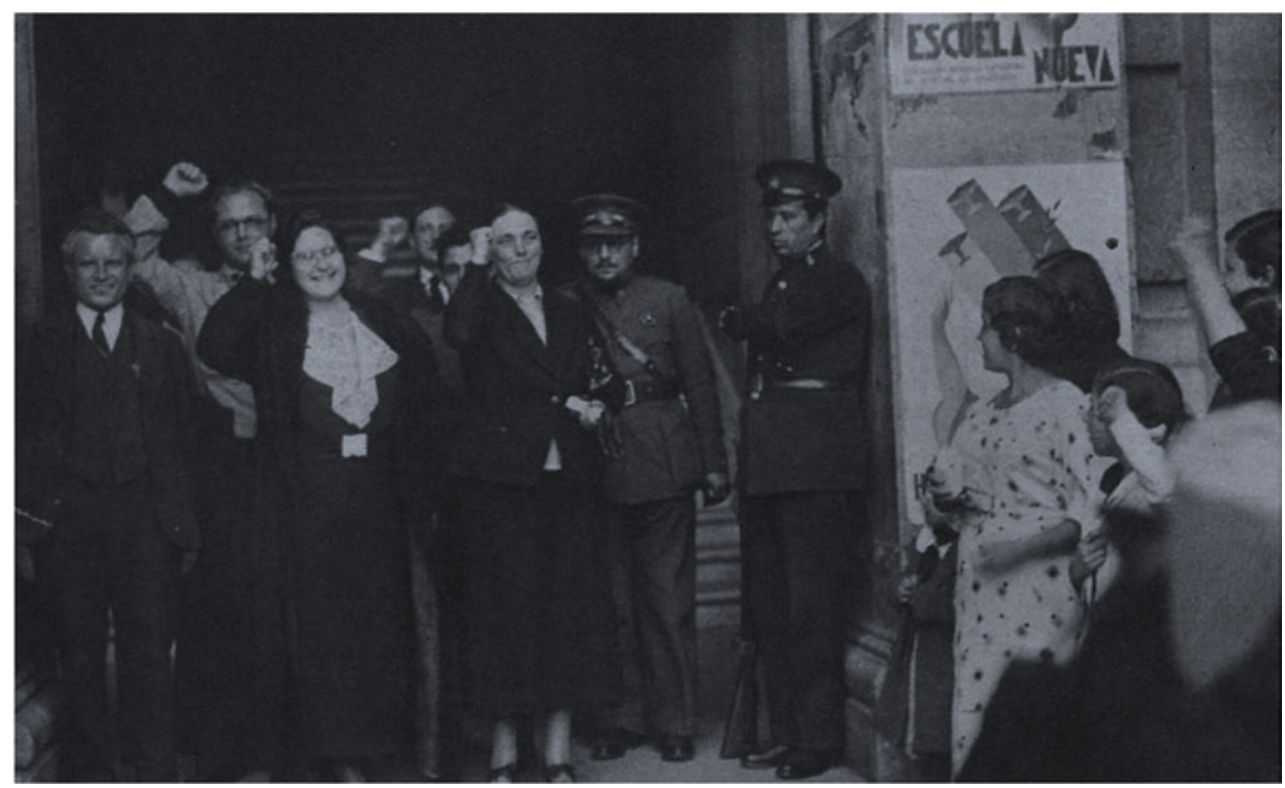

Imagen ıo. Crónica, 23 de mayo de I937, p. Io

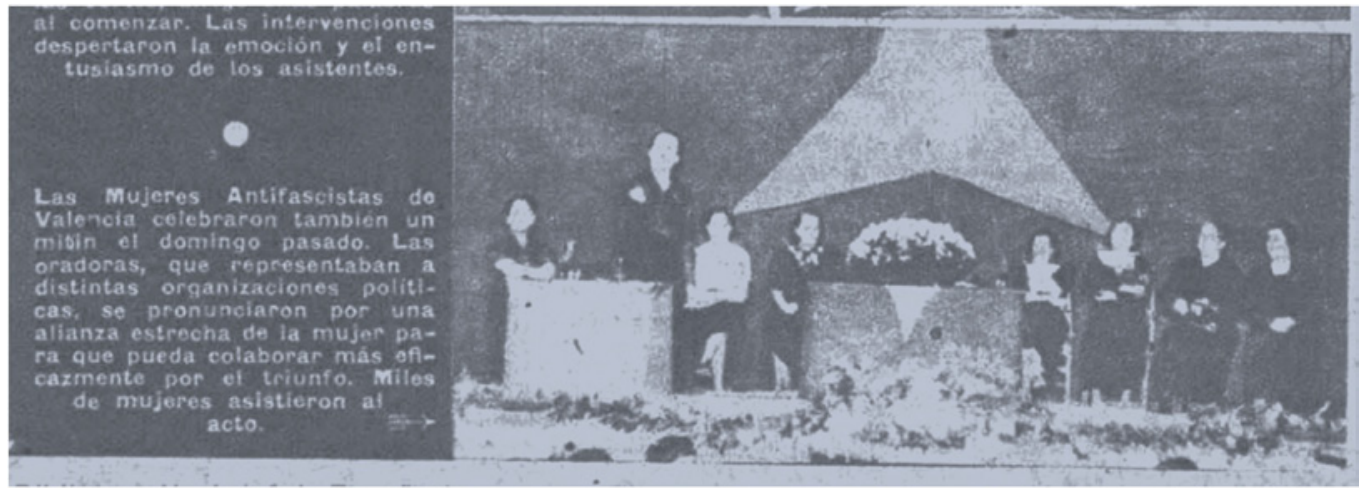

Imagen II. Crónica, 23 de mayo de I937, p. 20
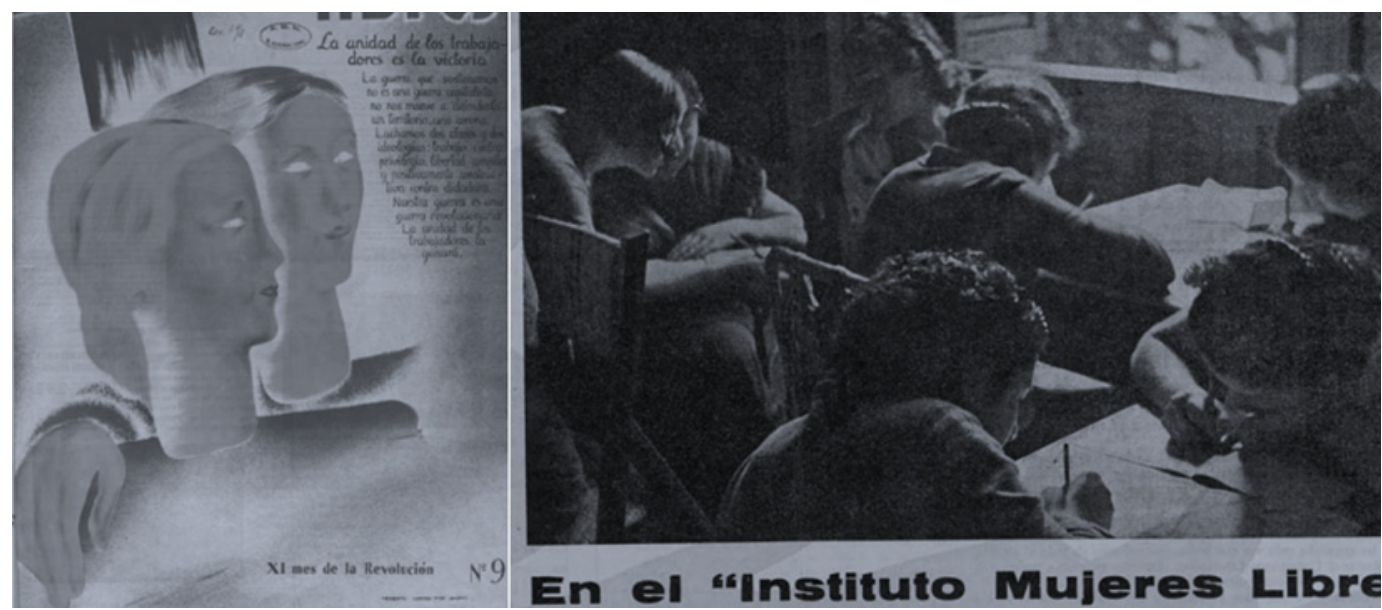

En el "Instituto Mujeres Libre

Imagen I2. Mujeres Libres, marzo de i937. Portada y página 7

Durante todo el trabajo hemos sugerido al alumnado la necesidad de una mirada escéptica y crítica hacia las fotografías por su carácter ambivalente y su prioritaria función propagandística. Era conveniente distinguir entre apariencias, retórica revolucionaria y realidades sociales. 
Continuidad y cambio siempre van de la mano en la dialéctica histórica. Sin embargo, los prejuicios y roles sociales de género son cárceles de larga duración y su alargada sombra aparece en imágenes que reflejan la segregación laboral y la división sexual del trabajo en los frentes donde las mujeres realizaron tareas de cocina, lavandería, sanitarias o administrativas.

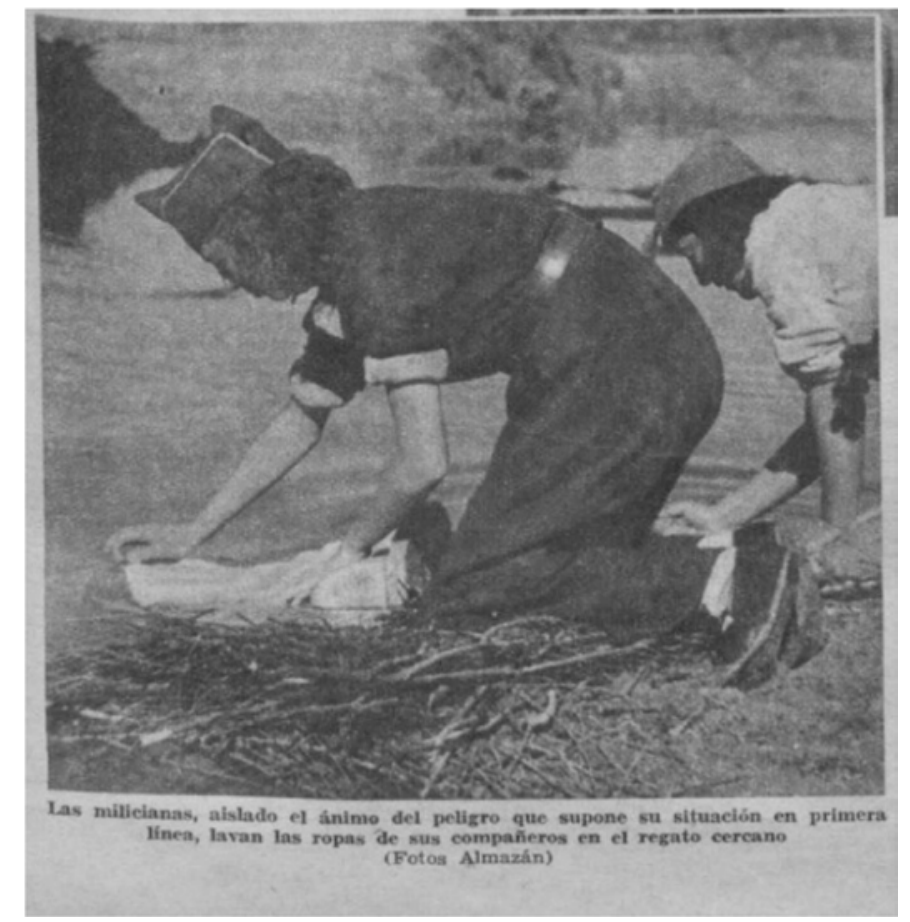

Imagen i3. Ahora, 4 de noviembre de 1936, p. 7

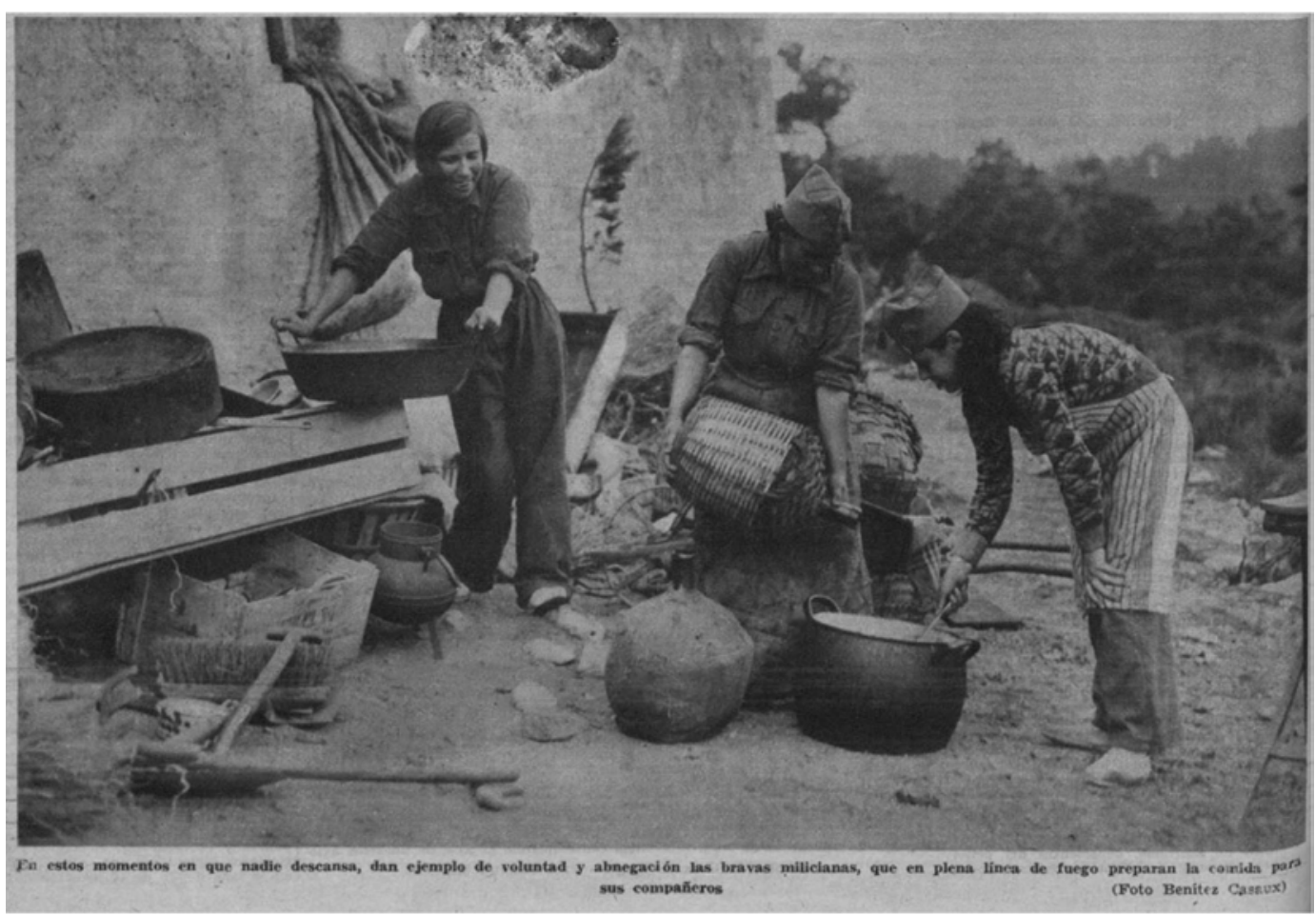

Imagen I4. Ahora, II de noviembre de I936, p. II 


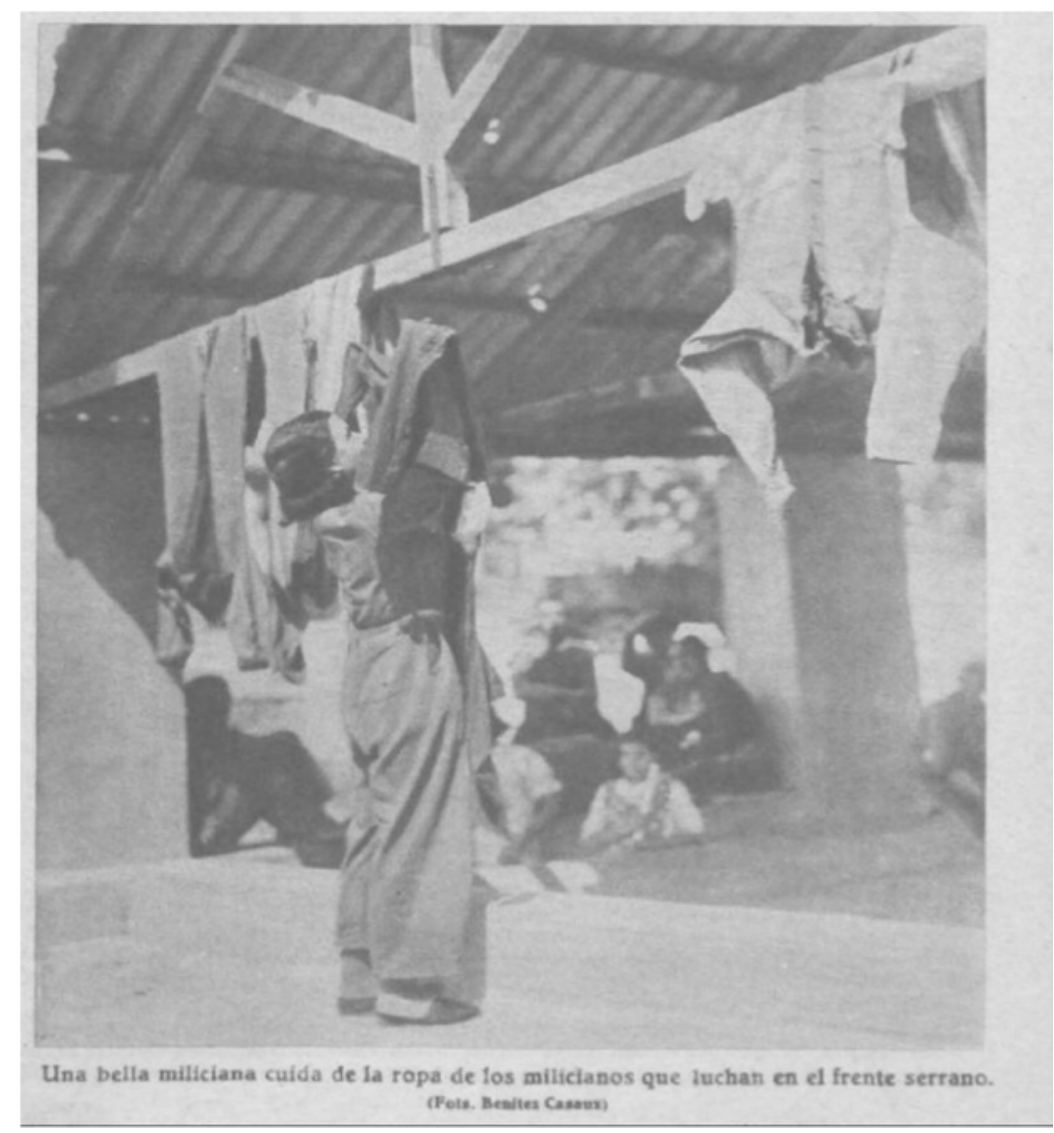

Imagen I5. Crónica, 20 de septiembre de I936, p. 3

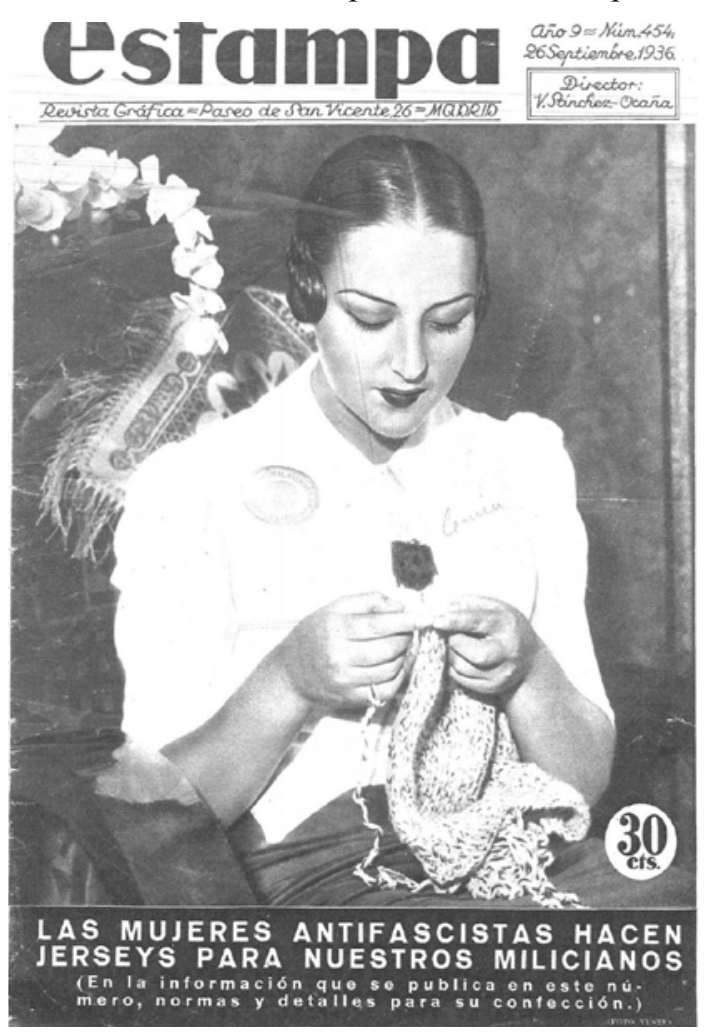

Imagen r6. Estampa, 26 de septiembre de 1936. Portada 
Por otro lado, las primeras actitudes positivas hacia la movilización de las mujeres se tornaron en viejos estereotipos y frases como "las verdaderas mujeres no traen la deshonra al frente" terminaron por asociarse injustamente con el problema de la prostitución y la propagación de enfermedades venéreas (NASH, 2006: 169).

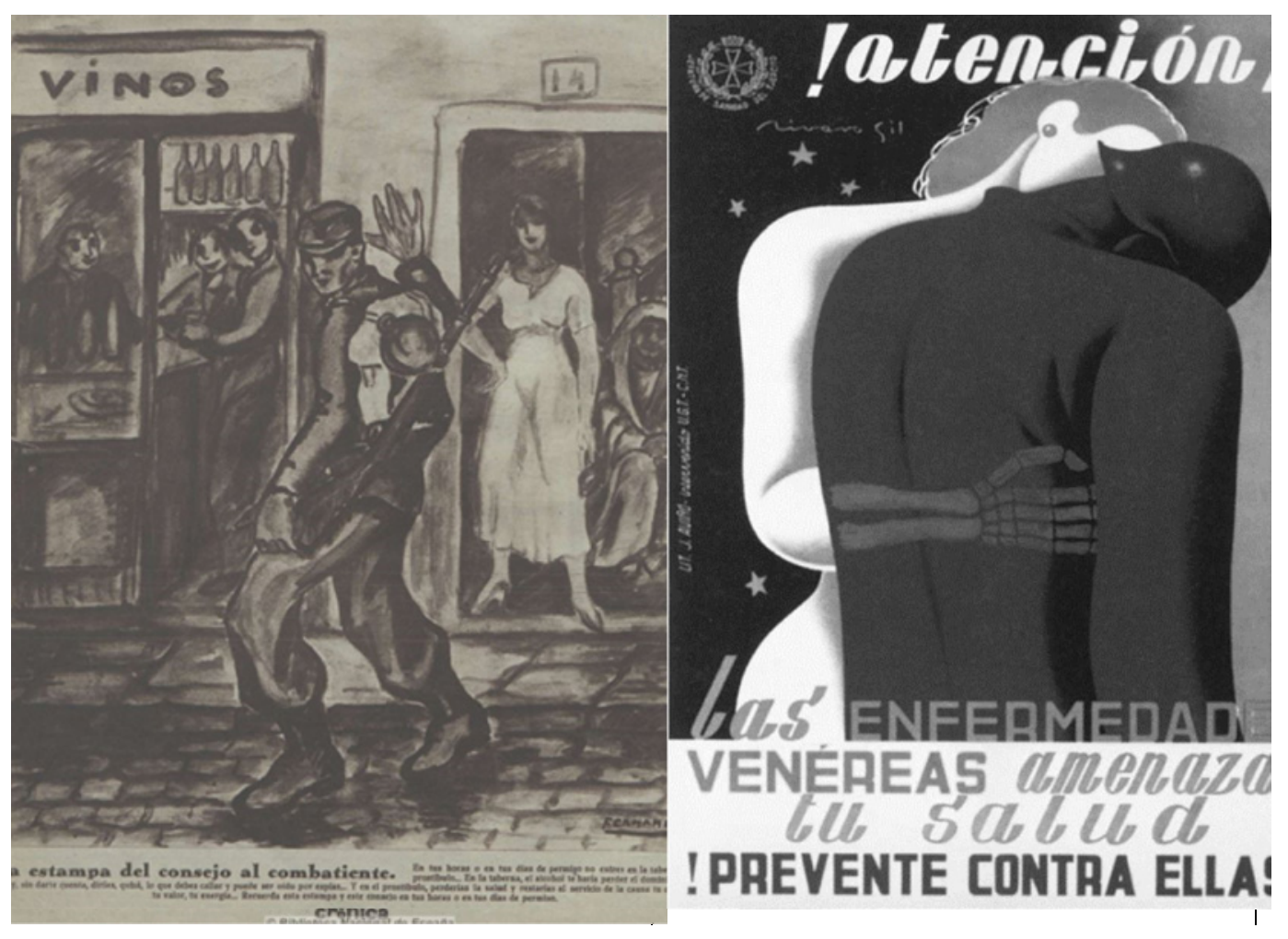

Imágenes I7 y 18. Cartel de Rivero Gil. Campaña contra las enfermedades venéreas, 1936-I939.

Crónica, 27 de julio de I937, p. 2

\section{LA IMPORTANCIA DEL ANÁLISIS VISUAL EN LA EDUCACIÓN HISTÓRICA}

En I915 se preguntaba Benito Pérez Galdós ¿Quién de vosotros no habrá tenido ocasión de observar al infeliz obrero o al rústico fatigado al fin de la jornada, buscando en las revistas gráficas su medio de comunicación con el mundo? La pregunta se hacía eco de uno de los fenómenos más característicos del periodismo de su época: la creciente incorporación de fotografías desde finales del siglo XIX en las revistas y los diarios (SÁNCHEZ VIGIL y OLIVEIRA ZALDUA, 20I4: I6). En la actualidad estamos inmersos en un proceso de cambio que presenta ciertos paralelismos con el planteado por Galdós. En un mundo en el que el ciudadano medio urbano consume cerca de 800 imágenes diarias es hora de que nos paremos a pensar lo que está pasando (ACASO, 2016: I2).

La dramatización artística de este exceso ha quedado plasmada en la instalación Photography in Abundance de Erik Kessels, presentada en 201 en el museo FOAM de Amsterdam. La instalación consiste en un volcado de cerca de un millón y medio de fotos - descargadas de internet e impresas a tamaño de tarjeta postal—extendidas por las diferentes salas del edificio. Esa cantidad se correspondería a la cantidad de archivos subido al portal Flickr durante un periodo de 24 horas. La saturación visual y sus consecuencias obligan a reflexionar y educar en la importancia de la imagen (FONTCUBERTA, 2016: 25) y la capacidad de los alumnos 
para su interpretación en un contexto donde se han convertido en un elemento esencial para la socialización y alfabetización de las nuevas generaciones.

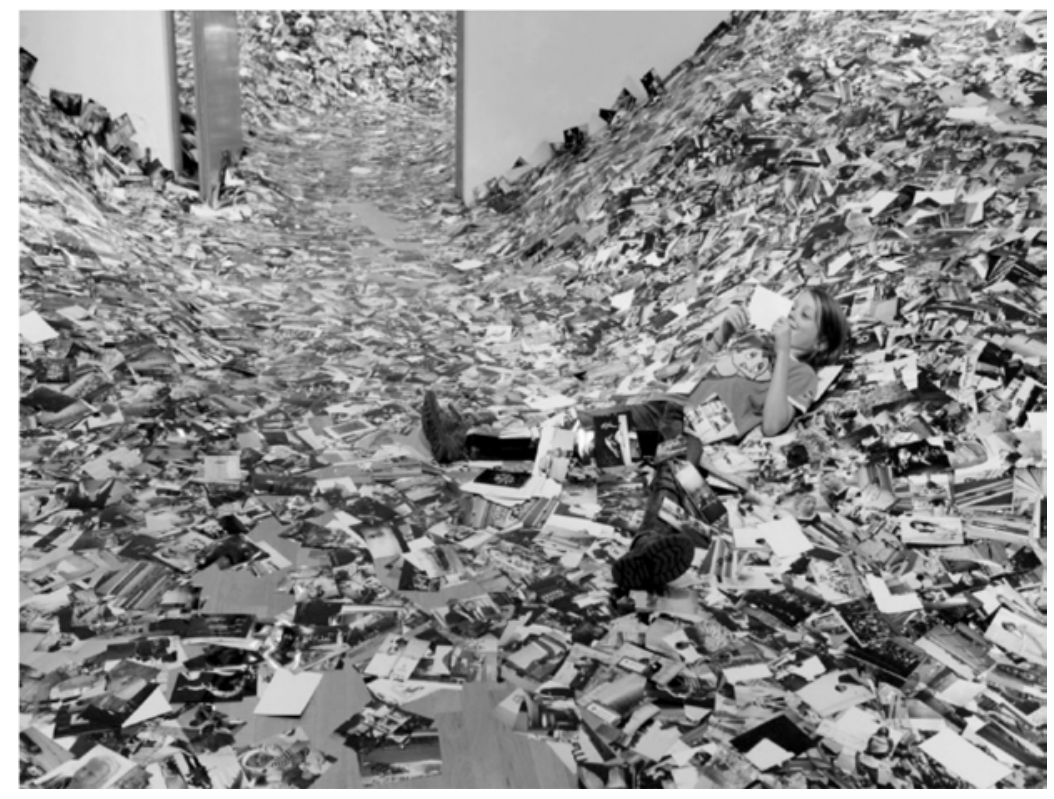

Imagen 19. Photography in Abundance de Erik Kessels, 20II

En historiografía, fue la historia cultural la que inició en los años noventa el conocido como "giro visual". Autores clásicos como Huizinga y Haskel subrayaron la importancia de lo visual (a través del Arte) en la imaginación y el pensamiento histórico. Por su parte, Roland Barthes destacó el carácter del lenguaje propio de la imagen cuya interpretación es posible gracias a las convenciones y reglas propias de su "retórica".

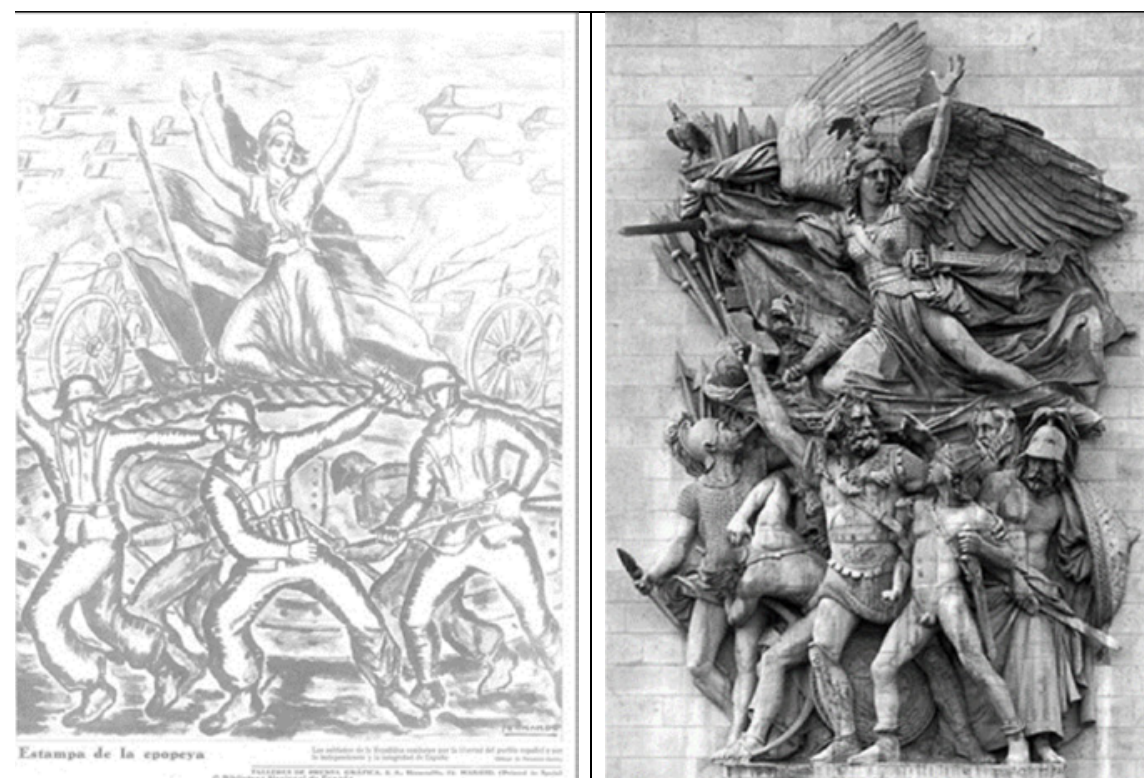

Imágenes 20 y 21. Crónica, 8 de agosto de 1937. Contraportada. François Rude, La partida de los Voluntarios de 1792 o La Marsellesa, $1832-1836$ 
Para Peter Burke las imágenes son documentos históricos que, al igual que todo vestigio del pasado, necesitan de una crítica externa e interna que nos permita dotarlo de un determinado grado de fiabilidad. El historiador cuenta con instrumentos para objetivar las fuentes, empezando por su clasificación (cuándo, dónde, por quién) y continuando por su interpretación, utilizando el utillaje heredado de planteamientos metodológicos enriquecedores como los de Panosfky (niveles de interpretación preiconográfico, iconográfico e iconológico) o Barthes y los significados denotativo y connotativo de la imagen (BURKE, 2005: 78).
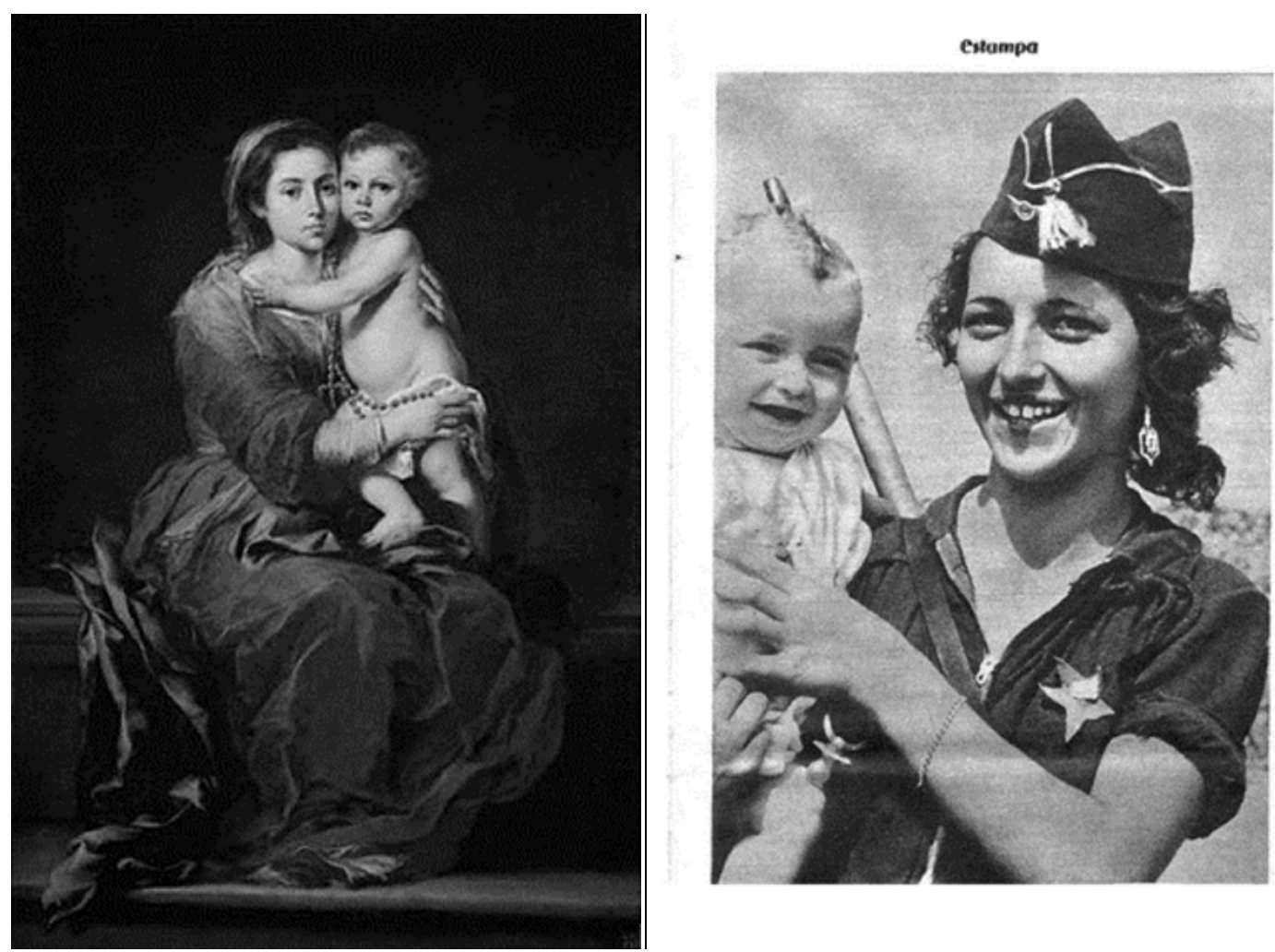

Imágenes 22 y 23. Bartolomé Esteban Murillo, Virgen del Rosario, I650-I655. Museo del Prado.

Estampa, 5 de septiembre de 1936, p. 9

La fotografía presenta un carácter dual pudiendo definirse como una forma de expresión y un medio de información y comunicación. En este sentido, las imágenes fotográficas seleccionarían y organizarían estéticamente un fragmento del mundo visible creando un testimonio (KOSSOY, 20I4: 108). Para Antonio Pantoja Chaves, la imagen fotográfica juega un importante papel en la transmisión, conservación y visualización de las actividades políticas, sociales, científicas o culturales de la humanidad de tal manera que se erige en verdadero documento social (PANTOJA CHAVES, 20I0: 179).

En consecuencia, la fotografía, como testimonio y documento social nos debe permitir acceder a lo que Gisèle Freund denominó la "trama histórica" de las imágenes desde una aproximación contextual que inserte la fotografía dentro del ámbito más amplio de la historia cultural. De igual modo, la imagen como testimonio histórico debe introducirse en el proceso de enseñanza del conocimiento histórico a través del aprendizaje de unas destrezas hermenéuticas que permitan interpretar el sentido iconográfico de las imágenes. 

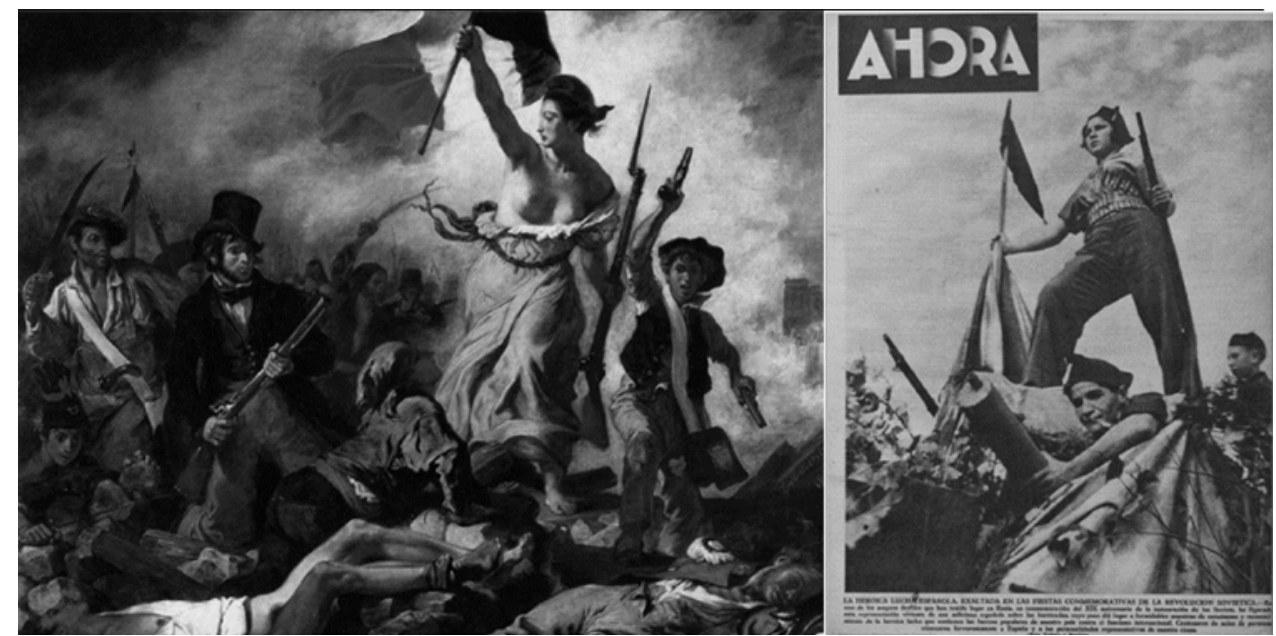

Imágenes 24 y 25. E. Delacroix, La Libertad guiando al pueblo, 1830. AHORA, 27 de diciembre de 1936

Una línea de investigación historiográfica que recoge estas inquietudes en España está representada por la obras de Mario Pedro Díaz Barrado y Antonio Pantoja Chaves de la Universidad de Extremadura y por Beatriz de las Heras en la Universidad Carlos III de Madrid. Para Díaz Barrado la inserción de la fotografía en la prensa a comienzos del siglo XX permitió el surgimiento de una nueva forma de narrar con imágenes que generó un efecto de memoria social en los contemporáneos (DÍAZ BARRADO, 20I2: I43). El reto actual consistiría en ser capaces de recrear un relato visual secuencial a través de las imágenes. Desde nuestra posición de docentes creemos que la didáctica de la historia debe ser capaz de educar la mirada histórica del alumno posibilitando el desarrollo de las destrezas que permitan leer las imágenes en el tiempo, descubrir la semántica del relato visual, la recurrencia de los marcos interpretativos, los significados contrapuestos que provoca la dinámica histórica de continuidad y cambio y la tensión entre memorias hegemónicas y contrahegemónicas.

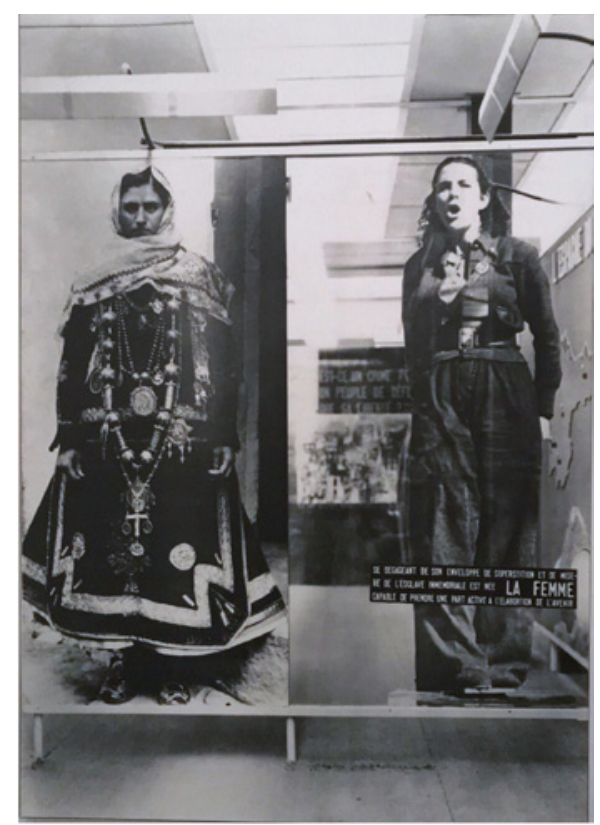

Imagen 26. Fotomontaje de J. Renau para el Pabellón Español de la Exposición Internacional de París en 1937 
Para Beatriz de las Heras las imágenes son poderosas herramientas de propaganda que, en momentos complejos de la historia como la guerra civil española, se convierten en soportes fundamentales y, años después, en documentos muy útiles para la recuperar la memoria de lo acontecido. El historiador y el profesor de historia pueden triangular diferentes fuentes visuales de carácter histórico que, a modo de elemento propagandístico, se utilizaron durante el conflicto y evaluar su significado. La pintura tendría su icono en el Guernica pintado por Pablo Picasso para formar parte del Pabellón Español de la Exposición Internacional de París de 1937. Los carteles, a modo de "gritos en la pared" se convirtieron en un medio muy eficaz de propaganda a través de su mensaje directo. Su proliferación con mensajes desde distintas ideologías, intencionalidades, géneros (alegoría, caricatura, ilustración, etc...) y formatos los ha convertido en una de las principales fuente visuales junto a la fotografía. En el caso de la fotografía resulta fundamental determinar los contextos de producción (la mirada y condicionantes de los fotógrafos) y de consumo, en virtud de la instrumentalización propagandística de las imágenes y la práctica de la censura (DE LAS HERAS, 20I7: I6).
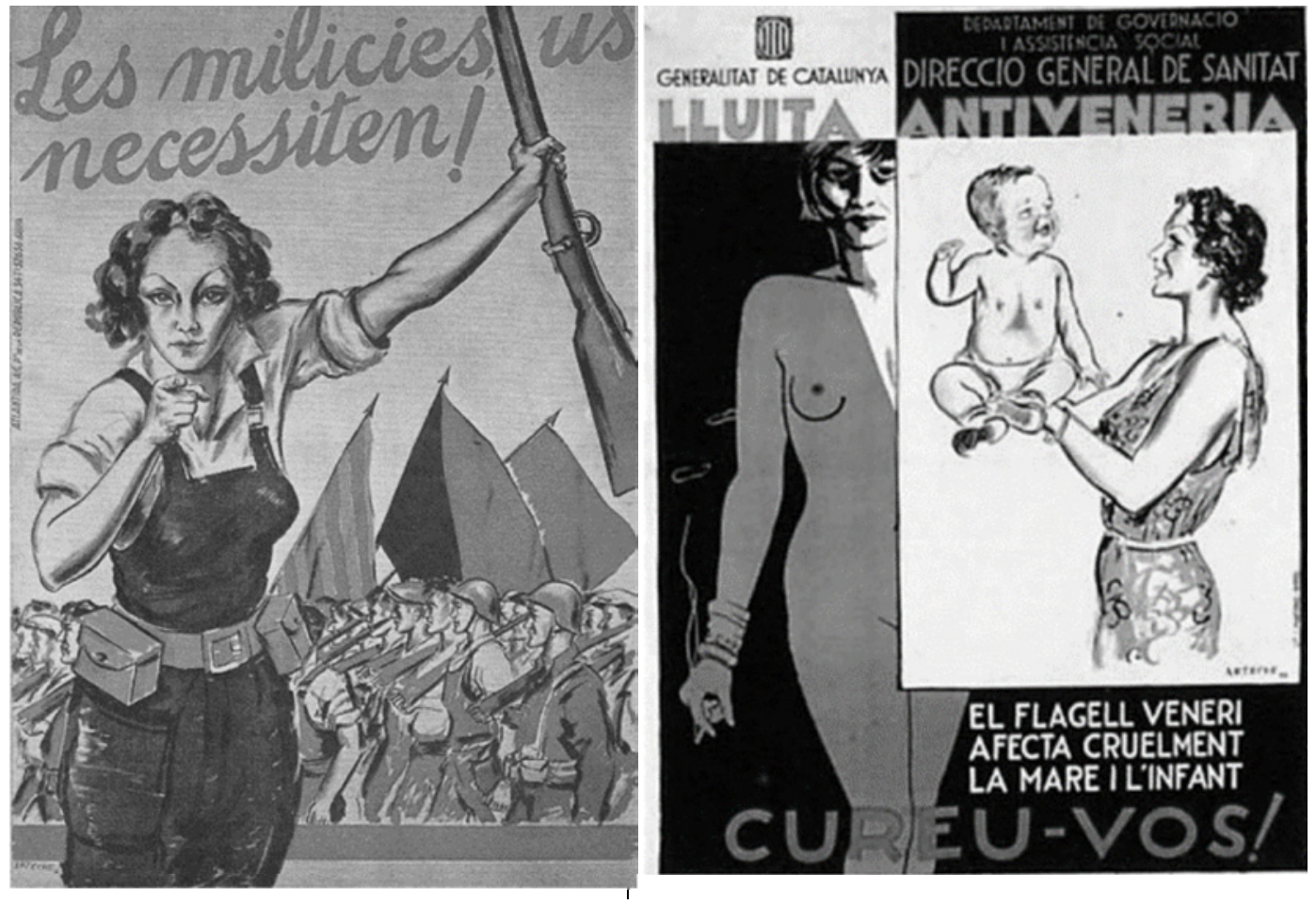

Imágenes 27 y 28. Carteles de Cristobal Arteche

Otra línea de trabajo interesante consiste en desarrollar las posibilidades de lo que se denomina arqueofotografía o Arqueología del Punto de Vista. Consiste en observar las fotografías de otra época y superponerlas sobre el paisaje actual. En nuestro trabajo ha sido un referente el blog <http://toledogce.blogspot.com/> dedicado a recuperar la memoria fotográfica de la Guerra Civil de la ciudad a de Toledo. 


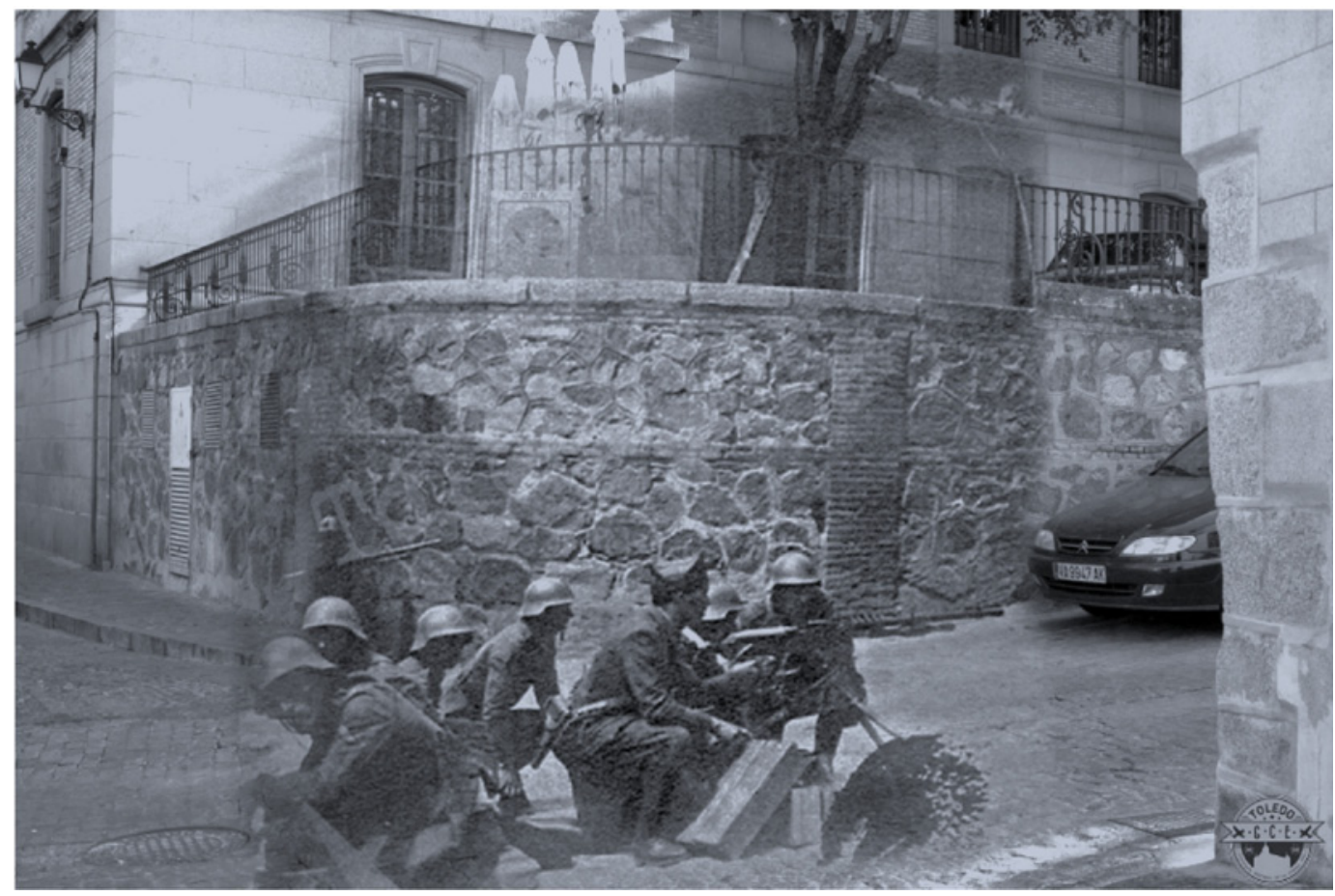

Imagen 29. Arqueofotografía. Tropas republicanas en la calle Santa Leocadia (Toledo)

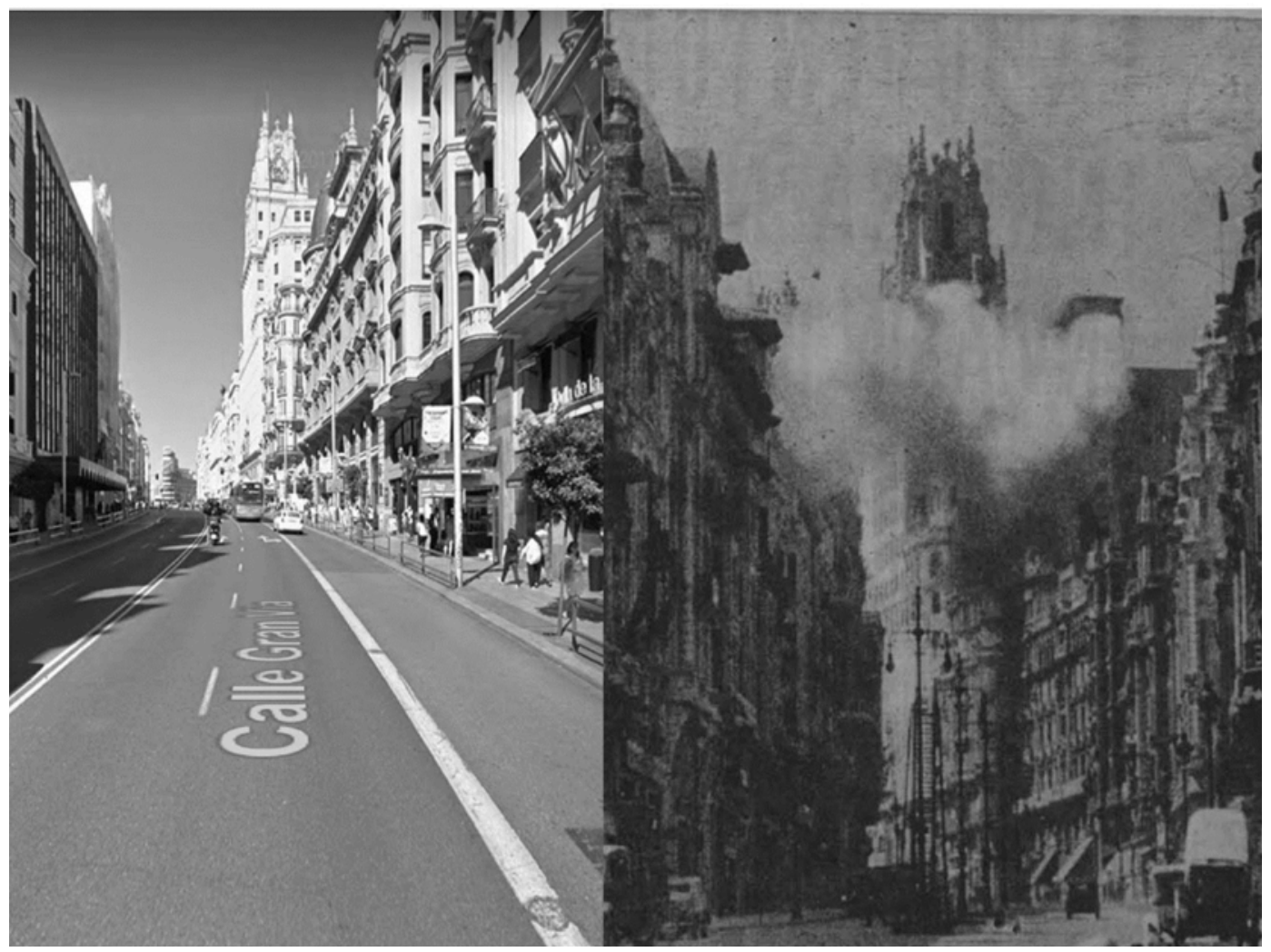

Imagen 30. Arqueofotografía realizada con la revista Ahora de 1936 y Google Maps por alumnos del IES Margarita Salas 
Por otro lado, en la actualidad muchas instituciones públicas como la Biblioteca Nacional de España con su Hemeroteca Digital y el Ministerio de Educación a través de la Biblioteca Virtual de Prensa Histórica han comenzado a digitalizar sus fondos mejorando la accesibilidad a las fuentes y facilitando nuevos usos al público general. En mayo de 2018 la digitalización por la Biblioteca Nacional de una colección de iı.ooo fotografías sobre la Guerra Civil tuvo una gran repercusión en prensa y redes sociales y propició una cierta esperanza para investigadores y docentes que podrán encontrar en estos archivos fotográficos o fototecas digitales rápido y fácil acceso a las fuentes en soporte digital. Para terminar este apartado, recordar que comenzamos hablando de la desmesura de la imagen en la época actual y la necesidad de una educación visual de carácter histórico, podemos concluirlo con las esperanzas que abren para la investigación histórico-didáctica el acceso a dichas fuentes.

\section{METODOLOGÍA PARA LA ELABORACIÓN DEL TRABAJO}

Aprovechando la mencionada accesibilidad a las fuentes de la prensa gráfica digitalizadas por la Biblioteca Nacional el alumnado, previa organización y reparto del trabajo con un sentido colaborativo por parte del profesor, comenzó a explorar algunas de las revistas gráficas más significativas del periodo a estudiar: Crónica, Estampa, Ahora, Juventud y Mundo Gráfico. Además de algún diario como La Vanguardia.

La tarea, emprendida durante el complicado tercer trimestre del último curso de Bachillerato, consistía en seleccionar todas las fotografías y fotorreportajes dedicados a un conjunto de temáticas: milicianas (portadas e imágenes interiores), trabajo de la mujer en la retaguardia y economía de guerra, participación política de la mujer, persistencia de los roles de género en el frente y la retaguardia, economía del cuidado: enfermeras, maestras y composiciones fotográficas inspiradas en clásicos de obras pictóricas (Goya, Delacroix, etc.) que con mayor atención buscaron los alumnos de la materia de historia del Arte.

La finalidad de la tarea estaba orientada a la creación de una colección fotográfica con documentación fotográfica sobre la temática de la mujer republicana en la Guerra Civil. El proyecto inicial estaba pensado para obtener unas 150 o 200 imágenes y finalmente se han llegado a recopilar más de rooo fotografías. En una primera fase el trabajo de análisis, selección y clasificación fue individual y posteriormente los alumnos publicaron todas las fotografías en una aplicación denominada Padlet que permite crear muros virtuales.

El proyecto no ha terminado ya que únicamente se ha realizado la colección sin entrar en la cuantificación de las distintas categorías (milicianas, retaguardias, oficios, etc.). Queda también pendiente para próximos cursos el análisis interno de cada fotografía y la determinación pormenorizada de sus contextos de producción y consumo. 


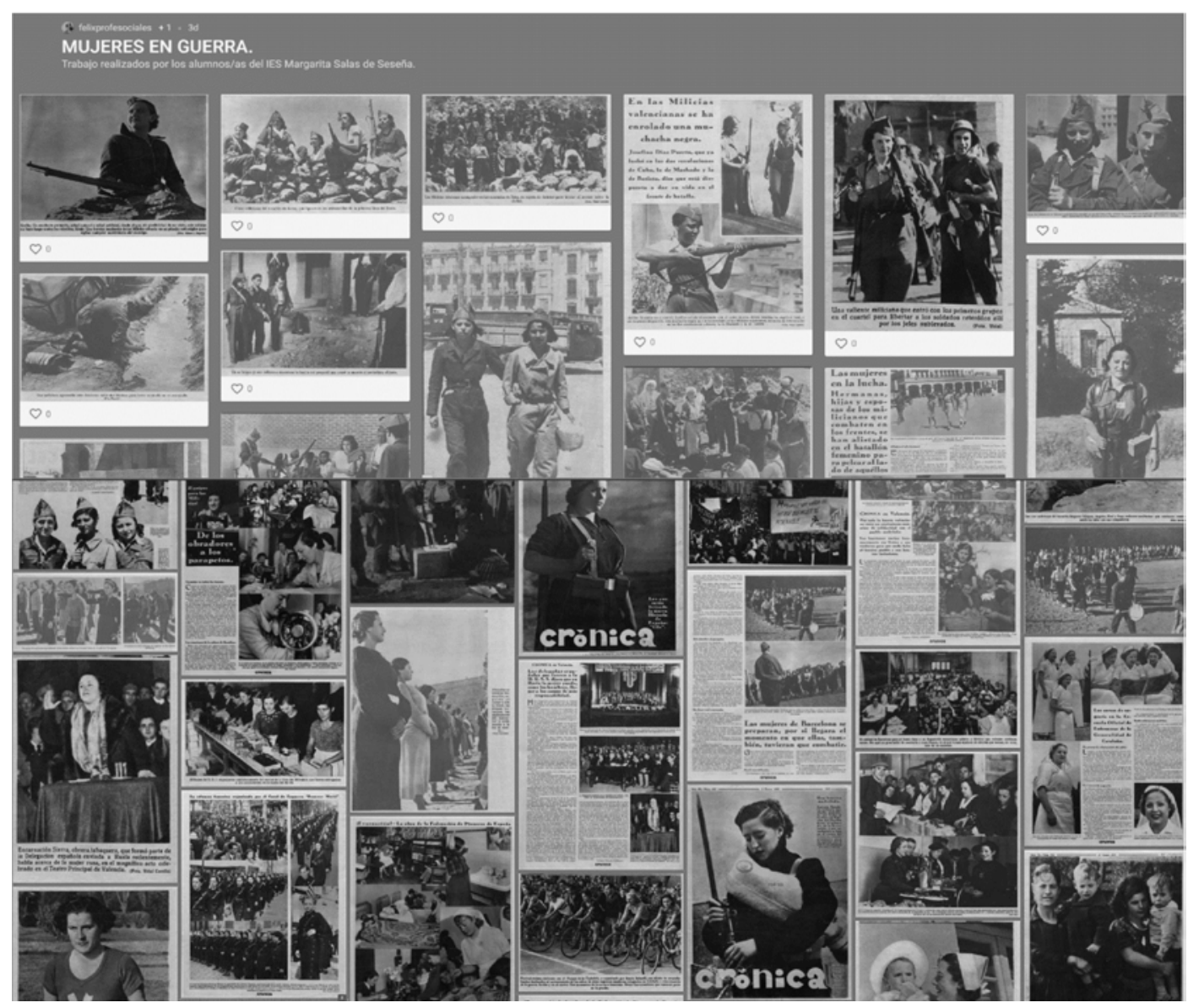

Imagen 3r. [En línea:] https://padlet.com/felixprofesociales/7zume6i2jyi8 [Visto: 6-I2-20I8]

\section{DIVULGACIÓN}

La elaboración del proyecto se ha desarrollado gracias al apoyo de los nuevos soportes digitales y trasmediáticos — páginas web, blogs, Facebook, cuentas de Twitter y medios digitales- y todos los resultados se han divulgado a través de estas nuevas formas de transmisión. Creemos que el objetivo de las Humanidades Digitales consiste en fomentar una conciencia y sensibilidad mediática en la era digital (PONS, 2018: 33) y la divulgación de trabajos escolares en red permite que el alumno descubra nuevos usos, aporte nuevos contenidos y enriquezca el entorno digital en que se desenvuelve. Por ello, los alumnos utilizaron las redes sociales más habituales para divulgar su trabajo (Twitter, Facebook e Instagram). 
[7. MujeresenguerralESMSalas retwitteó

Biblioteca Nacional @ @BNE_biblioteca.21 ago.

Aumnos del IES Margarita Salas y su profesor, @Felixgonchicote, han buceado en nuestra hemeroteca para realizar el proyecto de investigación histórica

@mujeresmsalas: más de 1000 fotografías de mujeres durante la Guerra Civil. ¡Enhorabuena por el trabajo!

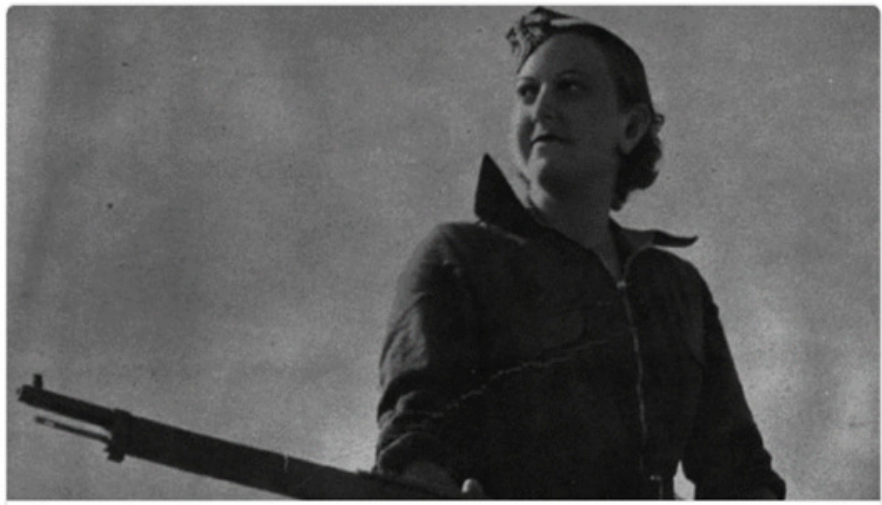

\section{MUJERES EN GUERRA.}

Trabajo realizados por los alumnos/as del IES Margarita Salas de Seseña. padlet.com

Imagen 32. Cuenta el Twitter del proyecto educativo
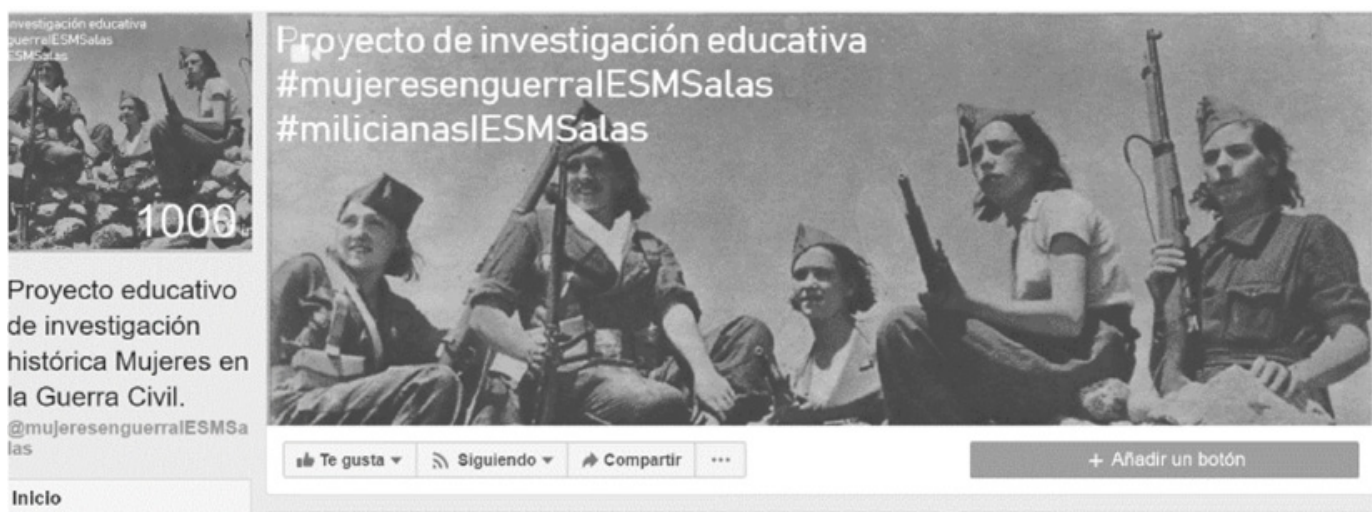

Iniclo

Publicaciones

Opiniones

Videos

Fotos

Información

Comunidad

Empleos

Grunos

Proyecto educativo de Investigaclón histórica Mujeres en la Guerra Clvil. ha compartido una publicación. 14 do agosto -6

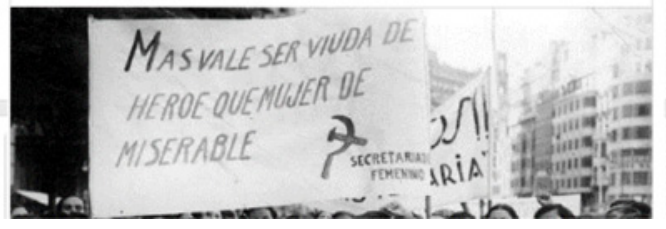

5.0

5 de 5 - Basada on la opinión do 1 porsona

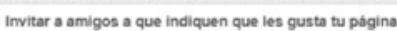

908

A Olga Garcia Feijóo, Pilar Vic Cristal y 44
personas más los gusta costo.

perang audiencia en Facobook para llegar a más personas que están interesadas en tu empresa.

Imagen 33. Cuenta en Facebook del proyecto educativo

Resultados parciales y actividades relacionadas con el proyecto han sido progresivamente publicados a través de las redes sociales (especialmente en Twitter) mediante etiquetas o bashtag que, en algunos casos, han tenido una repercusión y seguimiento importante. Baste con recoger los siguientes ejemplos: \#estudiamosconfuenteshistoricas \#milicianasMSalas \#mujeresenguerraMSalas \#historiaenfemenino2MSalas. 


\section{CONCLUSIÓN}

El análisis, en buena medida, serial de la documentación ha permitido un conocimiento más cercano y directo de los contenidos de la materia relacionados con el periodo de la Guerra Civil Española (I936-I939) situando la cuestión de la conquista del espacio público y la visibilidad del papel de la mujer en el eje de nuestro trabajo. Por otro lado, el conocimiento del "taller del historiador" ha permitido una mayor empatía con los agentes históricos y una reflexión sobre la motivación de las acciones individuales y colectivas, sus determinaciones y el contenido de sus esperanzas. El manejo de fuentes visuales ha familiarizado al alumnado en el laborioso proceso de elaboración del relato histórico ayudándole a establecer el distanciamiento crítico necesario en toda labor de comprensión que pretenda llevar a cabo el reto de aprender a pensar históricamente el presente.

\section{BIBLIOGRAFÍA}

Acaso, M. (2016): Esto no son las Torres Gemelas. Cómo aprender a leer la televisión y otras imágenes. Madrid: La Catarata.

Alonso Erausquin, M. (2010). Fotoperiodismo:formas y códigos. Madrid: Síntesis.

BURKE, P. (2005). Visto y no visto. El uso de la imagen como documento histórico. Barcelona: Crítica.

Cuesta, R. (2007). Los deberes de la memoria en la educación. Madrid: Octaedro.

Cuesta, R. (1998). Clío en las aulas. La enseñanza de la Historia en España entre reformas, ilusiones y rutinas. Madrid: Akal.

Díaz Barrado, M. P. (20I2). "La imagen en el tiempo: el uso de fuentes visuales en Historia”, Historia Actual Online, 29, pp. 14I-162 [En línea:] <https://historia-actual.org/index.php/numero-29-dehistoria-actual-online> [Visto: 04-08-2018]

Feliu Torruella, M. y Fernández Cardona, F. X. (2013). Didáctica de la Guerra Civil española. Barcelona: Grao.

Fontcuberta (2016). La furia de las imágenes. Notas sobre postfotografia. Madrid: Galaxia Gutemberg.

Gómez Carrasco, C. J. y Miralles Martínez, P. (2017). Los espejos de Clio: usos y abusos de la historia en el ámbito escolar. Madrid: Sílex.

Heras, B. DE LAS (2017): Imagen y Guerra Civil Española. Carteles, fotografía y cine. Madrid: Síntesis.

Kossoy, B. (2014). Lo efimero y lo perpetuo en la imagen fotográfica. Cátedra, Madrid.

Martínez Rus, A. (2018). Milicianas. Mujeres republicanas combatientes. Madrid: La Catarata.

Martínez Valcárcel, N. (20I4). La Historia de España en los recuerdos escolares. Análisis, interpretación y poder de cambio de los testimonios de profesores y alumnos. Valencia: Nau Llibres.

NAsh, M. (2006). Rojas. Madrid: Taurus.

Pantoja Chavez, A. (2010). "La fotografía como recursos para la didáctica de la Historia”. Tejuelo, 29, pp. 179-194.

Torruela, M. F. y Hernández Cardona, F. X. (2013). Didáctica de la Guerra Civil. Barcelona: Íber.

Pérez Garzón, J. S. (2000). La gestión de la memoria. Barcelona: Crítica.

Pons Pons, A. (2018). "La sensibilidad digital y la posición del historiador" en Eiroa San Francisco, M. (coord.). Historia y memoria en red. Madrid: Síntesis, pp. 2I-40.

Sánchez Vigil, J. M y Oliveira Zaldua, M. Fotoperiodismo y república. Madrid: Cátedra. 
